\title{
Culture in Corporate Law or: A Black Corporation, a Christian Corporation, and a Māori Corporation Walk into a Bar...
}

\author{
Gwendolyn Gordon*
}

\begin{abstract}
Recent Supreme Court cases have entrenched a new image of corporate civic identity, assigning to the corporate person rights and abilities based upon the cultural characteristics, social ties, civic commitments, and internal lives of the human beings involved in it. This vision of the corporation is exemplified in recent cases implicating a corporate right to engage in political speech (Citizens United v. Federal Election Commission) and a right of corporations to be free of government interference regarding religious convictions (Burwell v. Hobby Lobby Stores, Inc.). Although much is being written about the soundness of the results in these cases and potential inconsistencies of the legal analysis that led to these results, this Article uses these cases to introduce a normatively potent theoretical perspective on corporate law that has for too long been exiled to the periphery of legal theorizing. When persons, whether corporate or human, interact within a social system, social theories of culture-not just microeconomic theories of individual incentives or ethical theories of individual duty - are required to fully understand the rights, norms, behaviors, and duties of such persons. The law has transformed the cor-
\end{abstract}

\footnotetext{
* Assistant Professor of Legal Studies \& Business Ethics, The Wharton School, University of Pennsylvania. This Article has benefitted from comments at presentations at the 2014 conferences of the Law and Society Association, the Society for Business Ethics, the Academy for Legal Studies in Business, and the American Anthropological Association; as well as comments at conferences sponsored by Harvard's Institute for Global Law and Policy, the Ross School of Business at the University of Michigan, the University of Connecticut School of Business, and Wharton's Carol \& Lawrence Zicklin Center for Business Ethics Research. The Article has been shaped particularly by discussions with Elizabeth Pollman, Stephen Bainbridge, Lyman Johnson, David Millon, Cindy Schipani, Caroline Kaeb, Joseph Singer, and my colleagues at Wharton's Department of Legal Studies \& Business Ethics. I am grateful also to Ashley Super for her wonderful work as research assistant. This Article was written with the support of the Wharton Dean's Research Fund.
} 
poration into a unique civic person capable of holding and expressing opinions and beliefs to other members of its social community. This development urgently demands that corporate law scholars take cultural theory seriously if they are to fully understand the rights, norms, behaviors, and duties of modern corporations. This Article makes the case for the increased centrality of cultural theory within corporate law and lays out some of the major challenges and implications that lie ahead as this development takes hold.

\section{CONTENTS}

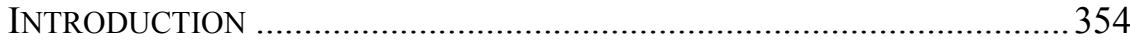

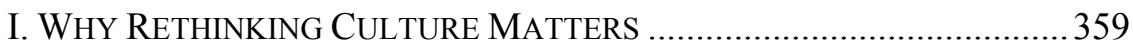

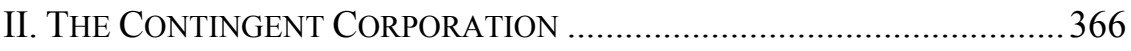

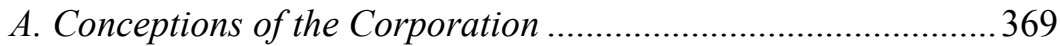

B. Solidarity and Disintegration in the Nature of the Corporation

III. A MĀORI-OWNED CORPORATION AND A MĀORI CORPORATION ... 384

A. The Indigenously Owned Corporation and the Indigenous

Corporation ....................................................................... 385

B. The Indigenous Corporation and the Contingent Corporation 390

CONCLUSION: THE LIVING CORPORATION ............................................... 394

\section{INTRODUCTION}

Many Americans only casually informed about the workings of the law were surprised to learn in early 2010 that corporations had suddenly grown inner lives. The Supreme Court, with its ruling in Citizens United v. Federal Election Commission, seemingly endowed firms with the ability to possess political opinions. ${ }^{1}$ In truth, American legal doctrine has long held that corporations have the potential for political speech. ${ }^{2}$ Relying heavily upon a characterization of the purpose of First Amendment political speech protections to be the safeguard of the right of listeners to hear as many different viewpoints as possible, the Court rendered protections for corporate political speech rights practically indistinguishable

1. Citizens United v. Fed. Election Comm'n, 558 U.S. 310 (2010).

2. See First Nat'l Bank of Boston v. Belotti, 435 U.S. 765 (1978); Buckley v. Valeo, 424 U.S. 1 (1976). 
from those for human persons. ${ }^{3}$ Citizens United garnered immediate and dramatic backlash for its blurring in law of socially important distinctions between human beings and corporations.

The courts, however, have continued to move in this direction. Four years after Citizens United, the Fourth Circuit decided that corporations could claim racial identities. ${ }^{4}$ The court's opinion in Carnell Construction v. Danville replicated the High Court's blurring of the distinctions between human and corporate rights. ${ }^{5}$ The Fourth Circuit mimicked the High Court in taking as settled the nature and extent of rights for corporations based in personal attributes - personal rights, let us call them ${ }^{6}$ and added a slight but important turn. In Carnell, an "imputed right" of a corporation to pursue an action on behalf of shareholders who had been discriminated against - established in the Eighth, Ninth, and Tenth Circuits ${ }^{7}$ - became an ability to be the "direct object" of discrimination. ${ }^{8}$ Then, with the June 2014 Hobby Lobby decision, the Supreme Court informed the nation that corporations have the ability to practice religion. ${ }^{9}$

These decisions seem to be peculiarly culturally inflected: they describe interior lives emergent-and inextricable - from social contexts. One might even call this an anthropological moment in corporate law jurisprudence. Legal anthropologists (myself among them) have found themselves caught between feelings of dismay over how corporate power has been conceptualized in the absence of a social theory for how these emergent persons should be free to behave vis-à-vis their surrounding communities, and excitement about the potential for a newly energized synergy between anthropological and legal takes on the corporation.

This Article advances the following thesis: The newly gained "maturity" of the corporate persons in our midst requires corporate law scholars to take seriously a concept they have long held at arm's length, namely, culture. Legal scholars have tended to prefer to elide cultural

3. See Citizens United, 588 U.S. at 360-70; see also infra notes 54-59 and accompanying text. 2014).

4. Carnell Constr. Corp. v. Danville Redevelopment \& Hous. Auth., 745 F.3d 703 (4th Cir.

5. Id.

6. While Citizens United focused on the rights of the audience to hear the expression of speakers, expression is at its roots about personal attributes: at the very least, intellect and conscience. Pac. Gas \& Elec. Co. v. Pub. Utils. Comm'n of Cal., 475 U.S. 1, 33 (1986) (Rehnquist, J., dissenting).

7. See Bains LlC v. Arco Prods. Co., 405 F.3d 764, 770 (9th Cir. 2005); Thinket Ink Info. Res., Inc. v. Sun Microsystems, Inc., 368 F.3d 1053, 1058 (9th Cir. 2004); Oti Kaga, Inc. v. S.D. Hous. Dev. Auth., 342 F.3d 871, 882 (8th Cir. 2003); Guides, Ltd. v. Yarmouth Grp. Prop. Mgmt., Inc., 295 F.3d 1065, 1072 (10th Cir. 2002) (imputed racial identity). See generally Richard R.W. Brooks, Incorporating Race, 106 COLUM. L. REV. 2023 (2006).

8. Carnell, 745 F.3d at 715.

9. Burwell v. Hobby Lobby Stores, Inc., 134 S. Ct. 2751 (2014). 
considerations because culture is so deeply complex, contingent, and resistant to the legal method of neat doctrinal analysis. Yet this phenomenon is precisely what must be considered if the law is to conceptualize corporations in a way that adequately respects important human interests and social values. And it is precisely the phenomenon that the discipline of cultural anthropology takes as its field of study.

The cases outlined in this Article evidence the courts' increasing willingness to conflate corporate rights and the rights of human beings, as well as their failure to articulate any clear picture of the contexts or the characteristics of corporations that might trigger or limit such rights. Without some theory of how these entities can or ought to interact with social norms, patterns of conduct, implicit constraints on the exercise of power, or societal wells of meaning, corporate law will cease to be connected to social reality. The recent financial crisis served as a confirmation of the notion that the world is messy and complex in ways that confound traditional, economically-focused perspectives. In response, economists and legal scholars are taking up new methods to preserve this messiness in their analysis in order to better understand what is happening in the world around them. The dominance of law-and-economics stances in corporate law has begun to yield to a diverse set of approaches that recognize the importance of culture. Cases like Citizens United, Carnell, and Hobby Lobby are producing novel questions to consider with these new techniques. The effort to incorporate anthropological theories of culture into our understanding of the corporation is now a matter of urgent interest.

As this Article will show, there are two primary reasons for this urgency. First, whether corporations are viewed as entities or as collections of individuals, their rights cannot be understood without a careful analysis of the corporation's social and contextual particulars. Scholars have tended to focus more on the connections between, and characteristics of, people within the corporation-hence the large literatures on corporate culture as a management and productivity variable. ${ }^{10}$ But corporations also spring from, and necessarily act upon, the cultural and legal norms that surround them. Second, once the study of the interaction between corporate persons and their cultural underpinnings comes into focus, a set of normatively important and challenging questions can be asked. For example, what influence should these cultural milieux have on the law? What limitations and exhortations should the law place upon them? How

10. See Langevoort infra note 21. 
should the cultural person of the corporation be related to its legal personhood?

An anthropological approach offers two tools that we might employ in answering such questions - one theoretical and the other methodological. Anthropology employs the concept of culture as a theoretical tool: as one lens through which to understand the world. Other approaches have other theoretical tools, their own lenses; economists, for example, may privilege efficiency or the maximization of human welfare as a normefficiency becomes their lens, something that matters in a way that can tell us something interesting about the world. Understanding the world through the lens of culture allows anthropologists to analyze complexities of human communal behavior otherwise hidden from view. Cultural anthropology gets at these complexities by means of a second tool-a distinct empirical method, that of ethnographic analysis. ${ }^{11}$ My work uses what the anthropologist Clifford Geertz called "thick description" to investigate relational aspects of corporate behavior. ${ }^{12}$ Thick description requires an intense attention to the context of human behavior in seeking to understand its significance to actors and interpret its meaning. ${ }^{13}$

This Article proceeds as follows. In Part I, I compare the ways in which the concept of culture is used in legal scholarship and anthropology regarding the corporate person. Once legal theorists of the corporation take culture seriously, we may recognize the importance of taking cultural considerations into account in theorizing what the corporation is and ought to be. The nature of the corporation (its essence, who owns it, from whom it gets the characteristics we are reading into it) and the relationships between the corporation and whatever is outside it become essential considerations. Thus, although it seems obvious that cases regarding

11. Anthropological ethnographic analysis focuses particularly upon long-term, in-depth qualitative study of some social grouping or phenomenon with an eye to understanding its dynamics. Studies will tend to be holistic and to involve many months of engagement with the group or phenomenon in question, often including interaction with people as they go about their lives.

12. ClifFord GEERTZ, THE INTERPRETATION OF CULTURES 5-6, 9-10 (1973).

13. The focus throughout the Article will be upon describing the processes and discourses by which outcomes are produced - upon making visible what, following Rosemary Coombe, I will call the cultural logic of corporate law, as it is expressed in these cases. See Rosemary J. Coombe, Culture: Anthropology's Old Vice or International Law's New Virtue?, 93 AM. SoC'y INT'L L. Proc. 261, 263 (1999) (describing the "cultural logic of intellectual property law"). For commentaries arguing the cultural nature of corporate law specifically, see Teemu Ruskola, Conceptualizing Corporations and Kinship: Comparative Law and Development Theory in a Chinese Perspective, 52 STAN. L. REV. 1599, 1604 (2000) ("[C]orporation law—like any other branch of law—grows out of a specific cultural tradition and intellectual history."). For two classic overviews of the connections between law and culture, see generally CLIFFORD GEERTZ, LOCAL KNOWLEDGE: FURTHER ESSAYS in Interpretive ANTHropology (1983); LAWrenCe Rosen, LAW as Culture: An INVitation (2006). 
race or the exercise of religion might be described as "cultural," subtler and far more significant is the manner in which the courts take into account - or do not take into account - the forces and frictions, internal and external, that make up the corporation.

In Part II, I use this anthropological idea of culture to analyze changes to the jurisprudence of corporations signaled by Citizens United, Carnell, and Hobby Lobby. ${ }^{14}$ These recent cases exemplify a vision of the corporation deriving socially oriented characteristics from its associated individuals. The corporation gains these characteristics from what looks like nothing so much as the "magical contagion" described in classical anthropology. ${ }^{15}$ I thus call this image of the nature of corporate rights the contingent corporation. The corporation-as-entity thus comes to be assigned the characteristics, social ties, civic commitments, and internal lives of the aggregate of humans involved with it. Importantly, this is not an entirely new image of the corporation. I review the similarities between the contingent corporation and the socially entangled corporatist bureaucracies of Émile Durkheim and Adolf Berle. Taking their work as a foil to the current moment in corporate theory, I historicize the corporation as a rights-holding entity in the eyes of the law in ways that have changed as society has. I use Citizens United, Carnell, and Hobby Lobby as examples that demonstrate how the concept of the corporation lends itself both to a salutary elasticity and toward particular conceptions of its place in society.

In Part III, I discuss the normative implications and theoretical challenges of using the lens of culture to examine corporate law and practice. To bring into view the types of insights to be gained from applying this cultural lens, I use an example from the long-term fieldwork I conducted with a New Zealand corporation owned by Māori people. ${ }^{16}$

14. Stephen Bainbridge cautions us to consider that perhaps the Supreme Court entirely lacks any such coherent corporate law jurisprudence. See, e.g., Stephen Bainbridge, Corporations Have No Right Under FOIA to "Personal Privacy," ProfessorBainBridge.COM (Mar. 1, 2011, 12:09 PM), http://www.professorbainbridge.com/professorbainbridgecom/2011/03/corporations-have-noright-under-foia-to-personal-privacy.html; Stephen Bainbridge, The Constitutional Rights of Corporations, PROFESSORBAINBRIDGE.COM (Sept. 29, 2010, 3:05 PM), http://www.professor bainbridge.com/professorbainbridgecom/2010/09/the-constitutional-rights-of-corporations.html.

15. See James Frazer, The Golden Bough (1890).

16. An important caveat: That I use this ethnographic data is not to claim that "Māori culture" or "indigenous culture" as totalizing wholes provide some example upon which American corporate law scholars might seize in order to improve American corporate law. The trope of an "indigenous wisdom" that might be used to help nonindigenous people (not, of course, the indigenous people), the trope of a "naturally" and homogenously more environmentally responsible indigenous "culture," and the trope of "a" culture as something indigenous people have (that naturally directs their actions) as opposed to "rational" nonindigenous people, are all problematic and often incredibly destructive tropes. Indeed, they are some of the ideas that have necessitated an ongoing project of 
Although an indigenously owned company may seem a far cry from the firms at issue in Citizens United, Carnell, and Hobby Lobby, there are surprising parallels. Further, the kind of culturally-sensitive, ethnographic research I conducted is quite close to the kinds of factual questions the Supreme Court would have us ask of corporations who seek to assert such things as religious beliefs on members of their communities, such as employees and their families.

The Article then offers a conclusion and lays out the work ahead as scholars begin the work of applying anthropologically informed cultural theory and research methods to help fill out the rights and duties of corporate persons. ${ }^{17}$

\section{Why RETHINKING CULTURE MATTERS}

In this Part of the Article, I sketch the genealogy of the concept of culture in legal scholarship on corporations, contrasting this with the development of the same concept in anthropology. I elaborate my stance on the importance of a modern anthropological concept of culture in the legal theorization of the rights attaching to the corporation.

For legal scholars of corporate law, the concept of culture has been an interesting but peripheral one. ${ }^{18}$ Of course, there has been some fine work done regarding corporations and culture. While acknowledging the

rethinking of the culture concept within the discipline of anthropology. See Coombe, supra note 13. As my explication of the concept in the next Part should make clear, these tropes are not what I mean by "culture," and this is not how I hope my examples will be received. A bounded "Māori culture" or "indigenous culture" is not the key here-it is the interactions between these people and these particular laws and this political moment. None of these may be unproblematically lifted wholesale to another context. Instead, I entreat you to pay attention to the interactions, the processes at work. The takeaway point is not about the uptake of notions of "indigenous wisdom" but about the ways state regulation and intragroup norms may be seen to give rise to, and reinforce, expectations for socially-oriented corporate behavior.

17. While the corporation comes in forms many and varied, I focus here specifically upon the for-profit business corporation.

18. See, e.g., Robert Cooter \& Melvin A. Eisenberg, Fairness, Character, and Efficiency in Firms, 149 U. PA. L. REV. 1717 (2001); Reza Dibadj, Reconceiving the Firm, 26 CARDOZO L. REV. 1459 (2005); Lauren B. Edelman \& Mark C. Suchman, The Legal Environments of Organizations, 23 AnN. Rev. Soc. 479 (1997); Amir N. Licht, Chanan Goldschmidt \& Shalom H. Schwartz, Culture, Law, and Corporate Governance, 25 INT'L REV. L. \& ECON. 229 (2005); Diane Vaughan, Toward Understanding Unlawful Organizational Behavior, 80 Mich. L. REV. 1377 (1982); Diane Vaughan, Rational Choice, Situated Action, and the Social Control of Organizations, 32 LAW \& SOC'Y REV. 23 (1998). There has also been some nifty law and society work holding culture to more sustained attention. See, e.g., John M. Conley \& William M. O’Barr, Crime and Custom in Corporate Society: A Cultural Perspective on Corporate Misconduct, 60 LAW \& CONTEMP. ProBs. 5 (1997) (using anthropological methods to query the concept of corporate misconduct in three case studies); Stewart Macaulay, Crime and Custom in Business Society, 22 J.L. \& SoC'Y 248 (1995) (classic legal ethnography by anthropologist Bronislaw Malinowski highly influential for Macaulay's study on the contract behavior of business people). 
concept's unwieldiness - the complexity that makes it both useful and difficult to use in legal analysis - some scholars have approached culture as something still interesting to, and even necessary for, law and economics. Robert Ellickson, for example, espouses a self-aware, sociologytinted $^{19}$ theory of culture that he accedes may "rest[] on simplifying assumptions" but nonetheless is worth considering. ${ }^{20}$ Donald Langevoort, also working to pin down the nature of culture in the context of the law and economics of corporations, has noted that while the concept is important for economic analysis, its "fuzzy" nature makes its proper place within law and economics scholarship difficult to discern: "One of the main objections to invoking corporate culture in rigorous legal analysis is that there is no clear definition of corporate culture." 21

For the most part the question in this situation has been: how can we make use of culture? In turn, the answer has tended to be: only tangentially - and only if we can define it and schematize it so that we are certain we know its meaning. The difficulty in pinpointing the meaning of culture has made cultural analysis challenging to deploy in corporate law scholarship. Compared to the streamlined elegance of law and economics, sophisticated cultural analysis - with all its unwieldiness and tendency to resist schematization - has had seemingly little to contribute. For the most part, on occasions where and when culture is taken into account in law and economics, it has tended to be addressed as a problem, a spanner in the works that must be made amenable to schematization and modeling. ${ }^{22}$

19. Robert C. Ellickson, Bringing Culture and Human Frailty to Rational Actors: A Critique of Classical Law and Economics, 65 CHI.-Kent L. REV. 23, 23 (1989); Robert C. Ellickson, The Evolution of Social Norms: A Perspective from the Legal Academy (Yale Law Sch., Program for Studies in Law, Econ. \& Pub. Pol'y, Working Paper No. 230, 1999) available at http://papers.ssrn.com/sol3/papers.cfm?abstract_id=191392; Robert C. Ellickson, The Market for Social Norms, 3 AM. L. \& ECON. REV. 1 (2001).

20. Ellickson, The Evolution of Social Norms, supra note 19, at 4.

21. Donald C. Langevoort, Opening the Black Box of "Corporate Culture" in Law and Economics, 162 J. InSTITUTIONAL \& THEORETICAL ECON. 80, 81 (2006).

22. Mark Roe, for example, aims to address the cultural complexities that tended to be ignored in modeling, and examines the ways in which this gaggle of complexities might limit the contractarian model of the corporation. Mark J. Roe, Can Culture Constrain the Economic Model of Corporate Law?, 69 U. CHI. L. REV. 1251, 1251 (2002). He concludes that it might, but only slightly. Id. at 1257. Nonetheless, Roe acknowledges that cultural background, while a variable ignored by most law and economics models, might be important in ways perhaps now invisible. Roe tests this supposition by means of a comparative sketch of takeover law-but culture does not erode the model only at its outer edges. A thicker concept of culture limits the contractarian model in different ways than does the concept as sketched by Roe. For instance, in his discussion of takeovers, Roe mentions in a brief aside - as an example of phenomena different from culture that might "also" constrain the economic model - the way legislatures act regarding impediments to takeovers, the 
There are several entirely distinct concepts of corporate culture, although their species-differences are seldom articulated. For example, the concept's most commonplace manifestation might be described as pop corporate culture-a concept notable for the practical uses to which it can be put, perhaps by managers seeking to shape corporate behavior and productivity or job seekers looking to increase their appeal to such managers. Legal literatures of corporate culture draw upon articulations of the nature of culture espoused within any of several disciplinary strains - for example, economics, organizational studies, or business ethics. ${ }^{23}$ Approaches influenced by economics or by organizational studies might query the way that people use or can use the concept of culture to improve business outcomes, ${ }^{24}$ while business ethicists might focus upon the extent to which cultural characteristics impact ethical reasoning and behavior. ${ }^{25}$ There is, of course, no "one true culture concept" and no one way to think about or use any version of the concept, but its different manifestations reveal (or conceal) different aspects of social life. Looking at efforts to define and theorize the notion of "corporate culture" reveals a number of assumptions implicit in legal scholarship.

way the polity accepts or does not accept antitakeover mechanisms, and the political muscle of managers. Id. at 1258. These are all aspects an anthropologist might study as cultural.

23. See, e.g., Geoffrey M. Hodgson, Corporate Culture and the Nature of the Firm, in Transaction Cost ECONOMics AND Beyond 249-69 (John Groenewegen ed., 1996); David M. Kreps, Corporate Culture and Economic Theory, in PerspeCtives ON POSITIVE POLITICAL ECONOMY 90, 109-110 (James E. Alt \& Kenneth A. Shepsle eds., 1990); George A. Akerlof \& Rachel E. Kranton, Identity and the Economics of Organizations, 19 J. ECON. PERSP. 9 (2005); Max H. Boisot, Markets and Hierarchies in a Cultural Perspective, 7 ORG. STUD. 135 (1986); Jacques Crémer, Corporate Culture and Shared Knowledge, 2 InDUS. \& CORP. CHANGE 351 (1993); Dennis A. Gioia, Majken Schultz \& Kevin G. Corley, Organizational Identity, Image, and Adaptive Instability, 25 ACAD. OF MGMT. REV. 63 (2000); Benjamin E. Hermalin, Economics \& Corporate Culture (Feb. 2000) (unpublished manuscript), available at http://faculty.haas.berkeley.edu/ hermalin/cultchds.pdf.

24. E.g., Yochanan Altman \& Yehuda Baruch, Cultural Theory and Organizations: Analytical Method and Cases, 19 ORG. STUD. 769 (1998); Andrew D. Brown, A Narrative Approach to Collective Identities, 43 J. MgmT. Stud. 731 (2006); Andrew D. Brown, Narcissism, Identity, and Legitimacy, 22 ACAD. Mgmt. Rev. 643 (1997); Lynn V. Meek, Organizational Culture: Origins and Weaknesses, 9 ORG. STUD. 453 (1988); John Weeks \& Charles Galunic, A Theory of the Cultural Evolution of the Firm: The Intra-Organizational Ecology of Memes, 24 ORG. STUD. 1309 (2003).

25. See, e.g., Thomas Donaldson \& Thomas W. Dunfee, When Ethics Travel: The Promise and Peril of Global Business Ethics, 41 CAL. Mgmt. Rev. 45, 45 (1999); Thomas W. Dunfee \& Thomas Donaldson, Contractarian Business Ethics: Current Status and Next Steps, 5 Bus. ETHICs Q. 173 (1995); Brian W. Kulik, Agency Theory, Reasoning and Culture at Enron: In Search of a Solution, 59 J. Bus. Eтнics 347 (2005); Ronald R. Sims \& Johannes Brinkmann, Enron Ethics (Or: Culture Matters More than Codes), 45 J. Bus. ETHICS 243 (2003); Andrew Spicer, Thomas W. Dunfee \& Wendy J. Bailey, Does National Context Matter in Ethical Decision Making? An Empirical Test of Integrative Social Contracts Theory, 47 ACAD. MGMT. J. 610 (2004). 
The genealogy of the concept of corporate culture within legal discourse has had real-world consequences. That genealogy was, for example, one lever for the legitimization of the very ideas of corporate political speech and corporate religion - of the notion that $a$ culture, $a$ religion, or $a$ political stance might be a solid, homogeneous thing held by these particulate, heterogeneous organizations.

The celebrated corporate takeover case of Paramount Communications, Inc. v. Time Inc. illustrates the enduring prominence of outmoded, static concepts of culture in the law. ${ }^{26}$ Consider "Time Culture," a concept portrayed by the defendants to be something very like the timeless totalities imagined by anthropologies of old. While the court engaged with this terminology in only the most reluctant terms - laden with scarequotes ("preservation of Time's 'culture"") or with oblique and carefully nondeterministic language - the concept of a unitary corporate culture nonetheless retained a sort of strategic legitimacy. ${ }^{27}$

This way of thinking about corporate culture is out of step, however, with modern conceptions of culture generally recognized in social scientific circles. Anthropologists - and social scientists more generally-nowadays do not tend to speak in terms of "a culture" or "the culture" of a group. Of particular interest here is an anthropological view of culture that takes the concept as an analytical device highlighting processes, tensions, and relations, rather than thing-like entities or identities. This view is best understood through contrast with its predecessor. ${ }^{28}$ Classically, an anthropological study might have considered culture to be manifested through a society's ceremonial clothing, its "timeless" traditions and practices, and/or its seemingly homogenous traditions of

26. Paramount Commc'ns, Inc. v. Time Inc., 571 A.2d 1140 (Del. 1990).

27. See id. at 1145, 1148 ("Time culture" references). Based on its liberal use of scare-quotes, the court appears to be gently skeptical of the concept; however, it does not reject it. The court makes no pronouncement as to the ultimate merit of the concept itself, but its finding in favor of Time may be seen as an imprimatur upon the company's use of the concept to advance its claims.

28. In the early 1900 s, culture tended to be viewed as something "superorganic"-as shared beliefs and practices effervescing up from groups of people to form something quite distinct from the individuals from which it arose - and thus able to order action in patterned ways over time. Researchers like Margaret Mead and Franz Boas popularized the superorganic conceptions of culture associated with their work in a way unmatched in anthropology since. Thus, Conley and O'Barr noted that the superorganic is the view of culture popularly associated with anthropology to this day: as concerned chiefly with "tribal" societies ruled by seemingly homogenous and unquestioned values and usually located elsewhere than the researcher's home society. John M. Conley \& William M. O'Barr, Crime and Custom in Corporate Society: A Cultural Perspective on Corporate Misconduct 60 LAW \& CONTEMP. PROBS. 5 (1997). The superorganic theory contrasts with a slightly later view taking culture to be merely a description of statistically-likely tendencies forming patterns for an aggregation of individuals. $I d$. at 9. 
thought. ${ }^{29}$ If we were to imagine culture in the form of a tent, we might say that these classic studies would focus upon the rods and pieces of fabric as constituting the essence of "the tent." Applying this lens to today's "corporate culture," these rods and pieces of fabric might be mission statements, historical brochures, and comportment guidelines.

More recent rethinking of culture, however, suggests a different perspective. ${ }^{30}$ Instead, the central concern is with the tensions and frictions between the rods and the stretches of polyester; the relationships between them; the forces that stick them together in the form we see as our tent. Concretely, we might look at the impact of legal rules and historical trends, various articulations of group boundaries and their effect on group identity, or power struggles as they shift over time. In short, this newer anthropological approach focuses not upon the pieces of the tent but upon the relationships between the pieces.

A reexamination of culture is crucially important for corporate law, where discursive deployments of the concept have had particularly dramatic effect; how we conceptualize culture has "worldly consequences that threaten to effect significant shifts in power and resources." ${ }^{31}$ Citizens United, Carnell, and Hobby Lobby are important not only directly but also in terms of the cultural narratives to which they contribute, which have real-world effects as well. Anthropological takes on law il-

29. For some background regarding these older images of anthropology, and critiques thereof, see generally ANTHROPOLOGY AND THE COLONIAL ENCOUNTER (Talal Asad ed., 1973); WRITING Culture: The Poetics and Politics of Ethnography (James Clifford \& George F. Marcus eds., 1986); 1 JeAn COMAROFF \& John COMAROFF, OF REVElation AND REVOlution (1991); CUlture/Power/History: A READER IN CONTEMPORARY SOCIAL THEORY (Nicholas Dirks, Geoff Eley \& Sherry Ortner eds., 1994); Culture, Power, Place: Explorations in CRitical ANTHROPOLOGY (Akhil Gupta \& James Ferguson eds., 1997).

30. The first of these is the recent reinterpretation of classic anthropological concepts of culture propagated by Franz Boas and his students, who "developed empathetic models of and methods for cross-cultural understanding; a historicist orientation to culture change; a sense of tradition as perpetually reconstructed in the present, engaging emotional attachments, and motivating secondary rationalizations; and a healthy suspicion of social science itself as always potentially just such a secondary ideological reflex of our own culture." Ira Bashkow, Matti Bunzl, Richard Handler, Andrew Orta \& Daniel Rosenblatt, A New Boasian Anthropology: Theory for the 21st Century, 106 AM. ANTHROPOLOGIST 433, 433-34 (2004). The second is the particular variant of Actor-Network Theory, espoused by the anthropologist Bruno Latour, which shows how disparate parts come to be perceived as concrete, whole, and self-sustaining actors-"black boxes." This concreteness is not stable but processual; it is continuously enacted. See John Law, Notes on the Theory of the ActorNetwork: Ordering, Strategy and Heterogeneity, 5 SYS. PRAC. 379, 381 (1992); see also Michel Callon, Some Elements of a Sociology of Translation: Domestication of the Scallops and the Fishermen of St Brieuc Bay, in Power, ACtion ANd Belief: A New Sociology OF KNOWledge? 196 (John Law ed. 1986); Jim Johnson, Mixing Humans and Nonhumans Together: The Sociology of a Door-Closer, 35 SOC. PROBS. 298 (1988).

31. Coombe, supra note 13, at 262. 
lustrate and foreground both these narratives and their effects on human lives. ${ }^{32}$ A number of corporate law scholars have persuasively argued the importance of judicial narratives in the development of the doctrine of corporate personhood and in corporate law theory more generally. ${ }^{33}$ As Teemu Ruskola has argued, decentering commonly held perspectives on these organizations is key in theorizing them. ${ }^{34}$ Given perspectives such as these, I anticipate an important role for anthropological takes on corporations in corporate law scholarship.

One of anthropology's main contributions in this respect may well be to change the kinds of questions we ask and the kind of "work" we expect the concept of culture to "do." Attention to the concept of culture in existing corporate legal scholarship recognizes that culture is im-

32. Regarding the value of anthropological theory in legal scholarship, Conley and O'Barr take from Stanislaw Malinowski's classic Crime and Custom in Savage Society the point that: "The anthropological perspective reminds us that we can benefit from putting law back into its cultural context, emphasizing the very connection between law and society that formal legal proceedings often seek to suppress" and that "human beings always practice in cultural ways." Conley \& O'Barr, supra note 18 , at 6 . Yet, anthropological scholarship and legal scholarship on corporations are seldom in conversation with one another; this despite a long history of anthropological scholarly engagement with corporations. See, e.g., Kim Fortun, AdVocacy After Bhopal: EnVIRonmentalism, Disaster, New Orders (2001); Stuart Kirsch, Reverse Anthropology (2006); Suzana Sawyer, CRude Chronicles: Indigenous Politics, Multinational Oil, and NeOliberalism IN ECUADOR (2004); June Nash, Anthropology of the Multinational Corporation, in THE POLITICS of ANTHRopology: From COLONIALISM AND SEXISM TOWARD A VIEW FROM BELOW 421 (Gerrit Huizer \& Bruce Mannheim eds., 1979). A newer body of scholarship works to theorize the corporation in anthropological terms, albeit not necessarily cultural ones. See, e.g., Leslie C. Aiello \& James F. Brooks, Corporate Lives: New Perspectives on the Social Life of the Corporate Form, 52 SuPPlement 3 CuRRENT ANTHRopology S1-S2 (2011); Robert J. Foster, Corporate Oxymorons and the Anthropology of Corporations, 34 DialeCtiCAL ANTHROPOLOGY 95 (2010); Stuart Kirsch, Imagining Corporate Personhood, 37 Pol. \& Legal Anthropology ReV. 207 (2014); Dinah Rajak, Theatres of Virtue: Collaboration, Consensus and the Social Life of Corporate Social Responsibility, 60 FOCAAL: J. GlobAL \& Hist. ANTHROPOLOGY 9 (2011); see also Greg Urban \& Kyung-Nan Koh, Ethnographic Research on Modern Business Corporations, 42 ANN. Rev. ANTHROPOLOGY 139 (2013). My own work is concerned with putting legal and anthropological theory in conversation; thus, it is the first work transporting insights from a modern anthropological view of culture into corporate law scholarship.

33. See Paul W. Kahn, the Cultural Study of Law: Reconstructing Legal SChOlarshiP (2000); Guyora Binder \& Robert Weisberg, Cultural Criticism of Law, 49 StAn. L. REV. 1149 (1997); Joel Edan Friedlander, Corporation and Kulturkampf: Time Culture as Illegal Fiction, 29 Conn. L. REv. 31 (1996); David Graver, Personal Bodies: A Corporeal Theory of Corporate Personhood, 6 U. CHI. L. SCH. RoundTABLE 235 (1999); Jeffrey Nesteruk, Corporate Theory and the Role of Narrative, 2009 MICH. ST. L. REV. 933 (2009); Warren J. Samuels, The Idea of the Corporation as a Person: On the Normative Significance of Judicial Language, in CORPORATIONS AND SOCIETY: POWER AND RESPONSIBILITY 113 (Warren J. Samuels \& Arthur S. Miller eds., Greenwood Press 1987); Gunther Teubner, Enterprise Corporatism: New Industrial Policy and the "Essence" of the Legal Person, 36 AM. J. CoMP. L. 130 (1988).

34. Teemu Ruskola, What Is a Corporation? Liberal, Confucian, and Socialist Theories of Enterprise Organization (and State, Family, and Personhood), 37 Seattle U. L. ReV. 639 (2014). 
portant insofar as it helps us to understand the behavior of corporations. Deserving of more attention, however, is the notion that culture might also be central to the question of what the corporation is. ${ }^{35}$ Cultural considerations suffuse not only the dynamics of the behavior of the corporation but also its legal theorizations - a point similar to that made regarding the link between scholars' political stances and their takes upon the value of different styles of corporate regulation. ${ }^{36}$ What we imagine the corporation to be (the ontological question absolutely foundational to any discussion of corporate law) and how we imagine the corporation should behave (our normative stance, inextricable from our view of the world) may both be analyzed as cultural questions. They might arise from ethical and political leanings. More fundamentally, they can come from our own theories as to how groups are formed and cohere, how preferences are prioritized within heterogeneous groups, and how we imagine the agentive status of the group and of individuals involved in those groups. That is, they come from our theories of culture, acknowledged or unacknowledged. Culture has everything to do with the conclusions we come to regarding the nature of corporations and their role in society.

In Citizens United, Carnell, and Hobby Lobby, cultural issues were implicated not only directly-via, for instance, the seemingly obvious cultural questions of the possibility of assigning racial or religious identity to a corporation - but also in the way the courts, the parties, and the public approached and came to conclusions regarding those questions. The result in each of these cases was controlled less by evident commitments to particular theories of the corporation than by particular, if unacknowledged, theories of the nature and dynamics of social groupsassumptions in regard to the importance of the individual within them, ${ }^{37}$ how they come to be, ${ }^{38}$ and who speaks on behalf of the group. ${ }^{39}$ In short, the Justices, and all of us, are closet cultural theorists. The task of unpacking what this means only benefits from a more anthropological perspective.

35. Cf. Geoffrey M. Hodgson, Corporate Culture and the Nature of the Firm, in TRANSACTION COST ECONOMICS AND BEYOND (John Groenewegen ed., 1996).

36. Roberta Romano, Metapolitics and Corporate Law Reform, 36 STAN. L. REV. 923 (1984) (demonstrating a link between typical political stances and the types of corporate law reform scholars suggest); see also Stephen M. Bainbridge, Competing Concepts of the Corporation (a.k.a. Criteria? Just Say No), 2 BERKELEY BuS. L.J. 77 (2005).

37. $C f$. Romano, supra note 36 , at $926-34$.

38. $C f$. Eric W. Orts, Business Persons: A Legal Theory of the Firm (2013); Katsuhito Iwai, Persons, Things and Corporations: The Corporate Personality Controversy and Comparative Corporate Governance, 47 AM. J. CoMP. L. 583 (1999).

39. For instance, questions of whether a "group belief" can exist in the context of heterogeneous belief, as opposed to something like a decision to take or not take an action. 


\section{THE CONTINGENT CORPORATION}

Conceptions of the behavior of the corporation have long evinced an individualistic and atomistic stance. Hence, for example, the version of group theorizing on view in Time - the idea evinced, even if not clearly articulated, that in looking at an aspect of the corporation that is based in some personal characteristic, you are looking at some discrete and bounded thing to which such a characteristic might be attributed - as we might think of a human individual. We might thus speak in terms of the (singular, unitary) corporation's (singular, unitary) identity or belief. Indeed, a group can speak with one voice, according both to common understandings and to legal ones. ${ }^{40}$

But whether thought of in terms of entity status or in terms of aggregate status, the corporation is better analogized to a community than to an individual. Instead of something that might be understood as simply evincing a certain personal characteristic (and here an analogue might be to personality characteristics amenable to psychological study), the corporation is an unbounded object which we must think of in terms of the interaction of multiple, diffuse tensions and forces-its various parts marked by and allotted with powers of agentive action and the disavowal of agentive action; with responsibility and lack of responsibility. ${ }^{41}$ Corporate personal attributes (e.g., the belief underpinning a free exercise claim; the "intellect and conscience" underpinning an act of political speech) and the nature of the rights arising out of them can only be understood in relational terms. ${ }^{42}$ To understand the corporation in terms of personal characteristics, we must, then, understand culture.

This modern anthropological view of culture allows us to more easily see the ways in which recent court decisions have begun to instantiate

40. We might consider newspapers, "official statements" of sports teams, or the political preferences of the Boy Scouts of America as an organization.

41. See Lawrence Rosen, Introduction: The Cultural Analysis of Others' Inner States, in Other INTENTIONS: Cultural CONTEXTS AND the ATtRIBUtion of INNER STATES 3 (Lawrence Rosen ed., 1995).

42. And not merely relationships involving shareholders and management. Here I reference, but resist, Stephen Bainbridge's conception of corporations as able to hold communities within them, but unable to become communities. On this point, Bainbridge has argued that while "the corporation may harbor within it sub-groups that amount to communities of shared values," nonetheless "a corporation's shareholders, creditors, and customers almost by definition cannot form communities. The host of familiar collective action problems that prevent shareholders from participating in corporate decisionmaking, for example, preclude them from developing any sense of community. Instead, true communities are most likely to arise among those who work for the corporation." Stephen M. Bainbridge, Community and Statism: A Conservative Contractarian Critique of Progressive Corporate Law Scholarship, 82 CORNELL L. REV. 856, 896 (1997). While it is beyond the scope of this article to engage fully with the vast legal and social scientific literatures on community, I refer to Bainbridge's critique to underscore the complexity of the issue. 
a unique theory of the corporation. Citizens United initiated, and Hobby Lobby extended, a new (or, more accurately, recovered) vision of the corporation-what I call the "Contingent Corporation." The term, with its reference to the classical anthropological concept of magical contagion, ${ }^{43}$ highlights the process by which distinctions between corporations and the people involved with them have been blurred and rendered more legitimate and intuitive, such that rights traditionally considered exclusive to human beings have been assigned to corporations. ${ }^{44}$ In Hobby Lobby, for example, the Supreme Court conflated the religious beliefs of the corporations' controlling shareholders with those of the firm itself. ${ }^{45}$ This understanding of the corporation assigns to the corporate person the cultural characteristics, social ties, civic commitments, and internal lives of the humans involved with it - not unproblematically.

The nature of corporations - and the nature of the rights and responsibilities these persons might therefore be properly accorded-is endlessly debatable. ${ }^{46}$ John Dewey's comments from early in the last century have, ever since, flavored the way that scholars have imagined the nature of the corporation (and the nature of debates over the nature of the corporation). Dewey argued that contemporary debates regarding the nature of corporate personhood were pointless without some acknowledgement of both the normative commitments of the arguers-where was our starting point, and toward what ideal did we aim? - and the empirical reality, the lived lives these ideals purported to describe. Whatever the state of debate, "person," Dewey wearily specified, "signifies what law makes it signify." $"$ This debate has taken place on many fields. ${ }^{48}$

43. See supra text accompanying note 15 .

44. The usage here is a distinct one and should be distinguished from, for example, Elizabeth Sheyn's "humanized" corporation. Elizabeth R. Sheyn, The Humanization of the Corporate Entity: Changing Views of Corporate Criminal Liability in the Wake of Citizens United, 65 U. MIAMI L. REV. 1 (2010).

45. See ORTS, supra note 38.

46. Consider the 1932 date of Max Radin's The Endless Problem of Corporate Personality, 32 COLUM. L. ReV. 643 (1932).

47. John Dewey, The Historic Background of Corporate Legal Personality, 35 YALE L.J. 655, 655 (1926) (internal quotation marks omitted). While it is easy to read Dewey to conclude that the debate is thus pointless, see id. at 669 , some have cautioned against this reading, calling it hasty. Orts cautions, "A close reading of Dewey ... suggests that he did not take the extreme position that the idea of legal personality should be abandoned. Dewey argued only that the idea itself should not drive legal and policy-related conclusions about the rights and obligations of legal persons." ORTS, supra note 38 , at 17 n.37.

48. For instance, classic scholarly debates on the corporation have mulled the status of the corporate person as real or imaginary, as the natural result of economic activity or as artificial creation of the state; the need for and the optimal extent to which corporations ought to be regulated in the interests of the public; what "ownership" of a corporation can or should mean; and the uses to which the corporate personhood idea may be put. See, e.g., Iwai, supra note 38; David Millon, Theo- 
Most at issue in regard to the Contingent Corporation is the question of whether the corporation is best theorized as an entity in itself or as a mere aggregation of individuals. Entity theories of the nature of the corporation take the "personhood" bit of corporate personhood to indicate that the firm is an actual, separate entity from its shareholders. ${ }^{49} \mathrm{Ag}$ gregate theories posit that the corporation is only and entirely the pile of human people, connected through actual or implied contractual relationships, that actually make up the firm. ${ }^{50}$ Aggregate theories have long dominated corporate law scholarship and tend to be associated with law and economics methodologies. ${ }^{51}$

Citizens United, however, troubled these theoretical distinctions. Rather than being explicable by reference either to an aggregate or an entity theory of the corporation, Citizens United appeared to be characterized by a combination of these two theoretical positions - or perhaps by one entirely different from either. The corporation was, the Court noted, a speaker, an entity. At the same time, its rights rose in reference to "people" who might be imagined as the constituents of the corporation or the audience-the American people.

To be sure, courts' treatments of the nature of the corporation have long exhibited inconsistencies. Throughout the last century, courts have switched cheerfully back and forth, sometimes mid-opinion, in the idea of the corporation on which their analysis rests. ${ }^{52}$ The current inconsistencies are different. They are characterized neither by blending viewsthe court does not merely take some hypothetical middle ground-nor by alternating between them. The current cases depend instead upon a dialectical view of the nature of corporations that holds aloft both theories at once.

These are old debates, but there are reasons that they continue. For example, while the question of the corporation's ability to hold constitutional rights has long been settled, the nature, extent, and context of any particular right so extended were questions quite unsettled prior to Citi-

ries of the Corporation, 1990 DuKE L.J. 201 (1990); Larry E. Ribstein, The Constitutional Conception of the Corporation, 4 SUP. CT. ECON. REV. 95, 96 (1995).

49. See generally Millon, supra note 48.

50. Id.

51. Id.

52. Reuven Avi-Yonah cites one instance of a vigorous use of such switchery in the case Hale v. Henkel, 201 U.S. 43 (1906). There, he relates, the Court managed to use by turns each of three different theoretical stances. "[H]aving clearly stated its reasons for limiting the application of the constitutional right, the Court suddenly reverted back to the aggregate view when faced with the question of whether corporations have any Fourth Amendment rights at all...." Reuven S. Avi-Yonah, Citizens United and the Corporate Form, 2010 WIS. L. REV. 999, 1016 (2010). 
zens United. ${ }^{53}$ Although Citizens United did not speak in terms of persons, the opinion expanded the conceptual space for corporations as something we could call "human-like" and for the idea that corporations' rights should be indistinguishable from the rights of individuals. ${ }^{54}$ It is this space for imagining corporations as human-like and thus naturally due rights once thought of as "personal" that gives rise to the Contingent Corporation.

This Part of the Article will work to unpack the implicit theorizations of the nature of groups and the nature of personhood that underlies these new changes. Subpart A will sketch the course of recent corporate law jurisprudence as it marks the Contingent Corporation. Subpart B will examine corporatism, one historical analogue of the present moment in corporate law and theory. Tracing two influential, ideal-typical views of the nature and the purpose of the corporation, subpart B will also consider what may be gleaned from a previous, similar (but not identical) moment of corporate entwinement with the personal characteristics of affiliated natural persons.

\section{A. Conceptions of the Corporation}

The Contingent Corporation blooms from Citizens United. First, the case normalized a mode of analysis that does not overly concern itself with the characteristics of different versions of the corporate form, instead erring on the side of characterizing rights based in personal attributes - traditionally considered applicable only to natural persons - as extendable to corporations and as indistinguishable in any relevant sense from the way the right is protected for human persons. ${ }^{55}$ This move, in turn, begat the simplified analysis of corporations' claims to rights based in personal attributes that is visible in Hobby Lobby. Of course, some of the gifts granted by Citizens United are at first difficult to discern; for instance, I contend that the notion of the nature of the corporation sanctioned in Citizens United led directly to the somewhat different-looking notion in Hobby Lobby. Yet even though Hobby Lobby departs slightly from the notion of the nature of the corporation championed in Citizens

53. See infra notes 54-59 and accompanying text.

54. For works exploring the establishment and earlier expansions of this conceptual space, see John J. Flynn, The Jurisprudence of Corporate Personhood: The Misuse of a Legal Concept, in CORPORATIONS AND SOCIETY: POWER AND RESPONSIBILITY 131 (Warren J. Samuels \& Arthur S. Miller eds., Greenwood Press 1987); Samuels, supra note 33; James Boyd White, How Should We Talk About Corporations? The Languages of Economics and of Citizenship, 94 YALE L.J. 1416 (1985).

55. Ellen D. Katz, Hobby Lobby and the Pathology of Citizens United, 9 DukE J. ConsT. L. \& PUB. POL'Y 23 (2014). 
United, articulation of that stance in the earlier case dramatically shaped the conceptual spaces that the corporation might properly be seen to occupy. The resulting image of the corporation in Hobby Lobby is, in fact, an attempt to hold entity and aggregate views of the corporation in generative tension.

An early corporate political speech precedent, First National Bank of Boston v. Bellotti, indicated that the questions regarding the protections of a "personal" right extended to corporations were necessarily contextual and openly "depend[ed] on the nature, history, and purpose of the particular constitutional provision." 56 But Citizens United, disclaiming the relevance of Bellotti's indications to the contrary, read the opinion to unambiguously indicate that corporations simply were speakers, indistinguishable from any other speakers, for the purposes of First Amendment speech rights. ${ }^{57}$ Thomas Rutledge's recent analysis of the appropriateness of a personal right for corporations affirms the Bellotti notion that "those protections are afforded on a case-by-case basis." ${ }^{~} 58$ Rutledge further emphasizes the limited and specific nature of corporate rights and the abiding importance of context. ${ }^{59}$ Rutledge's reading echoes that of Elizabeth Pollman, who outlined the previously nonbinary nature of the rights attaching to corporate persons. ${ }^{60}$ The bright-line approach favored by the current Court is a new development.

56. First Nat'l Bank of Boston v. Bellotti, 435 U.S. 765, 778 n.14 (1978) (stating a "personal right" refers to a right based not in "personhood" but in some personal attribute).

57. Id. at nn.14, 26; see also Katz, supra note 55, at 34 ("Citizens United notwithstanding, Bellotti itself never questioned that the political activities of corporations could be regulated more extensively than the political activities of individuals. Instead, Bellotti crafted what it described as a limited exception to that principle, making clear along the way that it was not ruling that corporations themselves possessed a First Amendment right to engage in political speech.").

58. Thomas E. Rutledge, A Corporation Has No Soul-The Business Entity Law Response to Challenges to the PPACA Contraceptive Mandate, 5 WM. \& MARY BUS. L. REV. 1, 24 (2014).

59. Rutledge notes:

For example, a corporation may be a 'person' with a defined citizenship who may access the federal courts by means of diversity jurisdiction. It benefits from due process and equal protection of the law, may exercise the rights of a free press, and enjoys protections against unreasonable search and seizure of its property. Conversely, a corporation has no Fifth Amendment right against self-incrimination and its due process rights are restricted as compared to those of natural persons. A First Amendment right to petition the government exists and a corporate expenditure with respect to an election may not be restricted on the basis of its corporate form, but political contributions by that same corporation may be restricted. A corporation has no right to vote, hold elected office, or sit on a jury. A corporation is not a person for determining the allocation of seats among the states in the House of Representatives. An indigent corporation is not entitled to stateappointed legal counsel.

Id. at 24-25 (citations omitted).

60. Elizabeth Pollman, Reconceiving Corporate Personhood, 2011 UTAH L. REV. 1629, 163031 (2011). 
But the Court's reading opened the door for new arguments and analyses regarding the extension of rights to corporations based in personal attributes. Contrary to the multifaceted analysis exercised in earlier cases, Citizens United appeared to indicate that a more simplified analysis might be appropriate. The former mode of inquiry asked whether, given particular circumstances and societal concerns, it made sense to extend a personal right to corporations - and if so, what ought to be the character and limits of those rights? ${ }^{61}$ In Citizens United, and later in Hobby Lobby, the inquiry is much less nebulous. Essentially, it focuses on one question only and reframes it in a somewhat reductive way: Does anything about the right at issue indicate that its protections ought not include corporations?

Corporate political speech limitations were, therefore, presumptively unconstitutional. Because nothing could be shown to indicate that speakers protected by the First Amendment did not include corporations, the government lost any ground to bar the corporation from enjoying the related personal right or to allow the state's discriminatory behavior. ${ }^{62}$ Regarding the development of the Contingent Corporation, the revolutionary effect of Citizens United is not a declaration that corporations have constitutional rights to political speech practically coterminous with those of natural persons, but that corporations have constitutional rights to political speech because they are, as speakers, practically indistinguishable from individuals.

This narrowing of the distance between the varied nature and rights of natural persons and those of corporations is the founding move in establishing the Contingent Corporation. The ultimate effect of Citizens United was to enable the curious linkage of entity and constituent rights on display in Hobby Lobby.

Citizens United's swift, matter-of-fact manner of dealing with the question of the nature of the rights that may validly belong to the corporation was one step toward granting legitimacy to the idea that personal rights might naturally belong to them. Not surprisingly, the case gave rise to a flurry of speculation as to what other "personal" rights might become available to corporations. ${ }^{63}$ As critiques and celebrations of the various possibilities emerged, so too did the political will to test the lim-

61. See generally id.

62. See Citizens United v. Fed. Election Comm'n, 558 U.S. 310, 339-41 (2010)

63. See, e.g., Josh Blackman, Do Corporations Have First Amendment Rights to Free Exercise of Religion?, JOSH BLACKMAN's BLOG (Nov. 28, 2012), http:/joshblackman.com/blog/2012/11/28/ do-corporations-have-first-amendment-rights-to-free-exercise-of-religion/; Ed Whelan, Wobbly Hobby Lobby Ruling in Favor of HHS Mandate, NAT. REV. (Nov. 20, 2012), http://www.national review.com/bench-memos/333808/wobbly-hobby-lobby-ruling-favor-hhs-mandate-ed-whelan. 
its. Opportunity arose in the form of the Affordable Care Act's birth control mandate.

The effect of Citizens United was thus not merely to reinforce political speech rights for corporations. More importantly, it fundamentally reframed the very debate regarding the rights imagined to naturally apply to human individuals versus those properly recognized as belonging to corporations. It empowered later courts to reconceptualize corporations in such a way as to essentially conflate and equate them with human persons. The implications of this convergence of categories are acutely important when it comes to the ability of corporations to have personal rights traditionally seen as applying only to "people" with some variety of internal mental, religious, or ethnic life. And crucially, this naturalization of the corporation will be key in legitimating further extensions of the personal rights that a corporation can be argued to have.

Given the "personal" nature of these rights, the Contingent Corporation's ability to "have" some particular cultural, racial, or political characteristic depends, to a not-insignificant extent, upon perceptions of the nature of ownership. Whose beliefs does the corporation hold? Whose opinions and preferences count when the corporation speaks? Dominant conceptions of ownership in the corporate context tend to take shareholding as only superficially different from the usual sense of dominion. While shareholders might relinquish control to management, this is generally assumed to be in the nature of an agency relationship: managers manage the owned property interest on behalf of the shareholders.

Some have argued, however, that this is a fundamental misapprehension of the nature of shareholding, the nature of management, and, indeed, the nature of the corporation. Instead of a relationship of management agency on behalf of shareholders, recent scholarship - and recent rereadings of classic understandings - cast shareholder ownership quite differently. ${ }^{64}$ Even were the character of corporate shareholding coterminous with other notions of property ownership, property is always a relationship; ownership always carries with it wider societal obligations. ${ }^{65}$ And just as notions of shareholding are being rethought, so too

64. Margaret M. Blair \& Lynn A. Stout, A Team Production Theory of Corporate Law, 85 VA. L. REV. 247 (1999); Paddy Ireland, Company Law and the Myth of Shareholder Ownership, 62 MOD. L. REV. 32 (1999); ORTS, supra note 38, at 54-62, 78-84 (arguing that agency understandings of the manager-shareholder relationship misread the nature both of agency law and of the relationship more generally); $i d$. at 159 (noting that even for the one-person corporation, doctrine uncontroversially supports a clear differentiation between "my" money and "the corporation's" money).

65. A point eloquently argued by progressive property scholars. E.g., Gregory S. Alexander et al., A Statement of Progressive Property, 94 CoRnEll L. Rev. 743 (2009); Gregory S. Alexander, 
has it become increasingly clear that arguments for shareholder primacy are not necessarily bound to arguments for share value maximization. In Hobby Lobby, for example, the Court dismissed the government's assertion that share value maximization was necessarily an overriding requirement in corporate management-but it did not dismiss the notion of shareholder primacy. Justice Alito's initial framing of those who matter in determining the corporation's views included shareholders, officers, and employees. ${ }^{66}$

Ultimately, however, the religious beliefs that ought, in the Court's estimation, to rule the corporation's "beliefs" were those of the controlling shareholders. ${ }^{67}$ In considering a corporation's personal attributes, we have to know which constituencies we ought to look at to find them. When the government posed this question at oral argument in Hobby Lobby, Chief Justice Roberts and Justice Scalia answered quite elegantly:

[Solicitor] General Verrilli: ... Your Honor, what are you going to do if there's a dispute between-let's say there are three shareholders-a dispute between two in the majority and one in the minority? You're going to have to get yourself involved - the courts will have to get themselves involved in all kinds of-

Justice Scalia: Whoever controls the corporation. Whoever controls the corporation determines what the party-

The Social-Obligation Norm in American Property Law, 94 CoRNELl L. REV. 745 (2009); Jedediah Purdy, A Freedom-Promoting Approach to Property: A Renewed Tradition for New Debates, 72 U. CHI. L. Rev. 1237 (2005); Joseph William Singer, Democratic Estates: Property Law in a Free and Democratic Society, 94 CoRNell L. REV. 1009 (2009).

66. Burwell v. Hobby Lobby Stores, Inc., 134 S. Ct. 2751, 2768 (2014) (“An established body of law specifies the rights and obligations of the people (including shareholders, officers, and employees) who are associated with a corporation in one way or another.").

67. And controlling officers only because these were, within both companies, the same people. That belief matters is, uncontroversially, an essential part of a free exercise claim; RFRA's definition of the free exercise of religion, while discrete and distinct from that within the First Amendment, does not excise this requirement. Although RFRA analysis does not demand evidence that an exercise be "compelled by, or central to, a system of religious belief," the requirement of the presence of the assertion of belief in some such system is quite clear. Regarding the ability of the corporate entity to have beliefs, the Court cited as "true-but quite beside the point." Burwell, $134 \mathrm{~S}$. Ct. at 2768. The Third Circuit's opinion also stated that "[g]eneral business corporations do not, separate and apart from the actions or belief systems of their individual owners or employees, exercise religion." Conestoga Wood Specialties Corp. v. Sec'y of U.S. Dep't of Health and Human Servs., 724 F.3d 377, 385 (3d Cir. 2013) (emphasis added). But the Court does not read the beliefs of the corporation to be "separate and apart from" those of the corporate entity: "Corporations, "separate and apart from' the human beings who own, run, and are employed by them, cannot do anything at all." Burwell, 134 S. Ct. at 2768 . The Court is able to minimize discussion of the beliefs of the corporation "on its own terms"- the beliefs of the corporation "itself"- precisely because with this comment it made coterminous the beliefs of the corporation and the beliefs of the human beings (specifically the controlling human beings) associated with it. 
[Solicitor] General Verrilli: And then-and the minority shareholder will say, well, this is - under state law, this is an act of oppression and this is-

Chief Justice Roberts: Well, that's a question of State corporate law. ${ }^{68}$

Leave it, that is, to shareholder democracy. The answer belies a number of critical assumptions about ownership and about the nature of personal attributes for corporations. That is to say, for Scalia, and for the Court, we may read personal attributes into corporations because:

1) Shareholders have personal attributes;

2) Shareholders own the corporation; and

3) As owners, they may use the expedient of shareholder democracy to decide that the corporation simply has the attribute at issue: it is a Muslim corporation, a Native American corporation, or what-have-you.

An interesting conception of property rights must necessarily underlie this viewpoint, one that appears oddly bound up in what might usually be considered a conventional aggregate view of the firm. If the corporation is an aggregate of individual shareholders-owners, it makes sense in this view that shareholders will have originary say over what the corporation does (by way of their chosen managers). But there is, in an aggregate theory of the firm, no necessary linkage between the shareholders' personal attributes and those of the corporation.

Yet when it came to imagining whose preferences, priorities, and personalities ought to bestow upon the corporation its "personality," it was the perception of corporate ownership as simultaneously characterized by and necessitating shareholder primacy that emerged as dominant. It is unsurprising, then, that scholars and laypersons alike seem to more easily attribute ethnicity, race, or religion to closely held corporations, and this appears to become more pronounced the more closely held the corporation is perceived to be. ${ }^{69}$ The closer the imagined link between shareholders and the corporation, the easier the conceptual transfer of the former's identities, rights, and preferences to the latter.

However, the Court's failure to clearly articulate this transfer's legitimating characteristics, as well as its practical limits, is highly problematic. In fact, the Hobby Lobby Court's loose, commonsense deploy-

68. Transcript of Oral Argument at 52-53, Burwell v. Hobby Lobby Stores, Inc., 134 S. Ct. 2751 (2014) (No. 13-354) (transcript refers to former-Secretary Kathleen Sebelius), available at http://www.supremecourt.gov/oral_arguments/argument_transcripts/13-354_3ebh.pdf.

69. See ORTS, supra note 38 , at 157-58. 
ment of the term "closely held" renders the term's referential status problematic as a matter of doctrine. As the Court does not distinguish between the many ways in which a corporation might be defined as closely held, the term acts as a failed limit. Yet, the pertinent question is not whether a claimant corporation is or is not closely held. The Court focused much of its analysis upon the closely held nature of Hobby Lobby and Conestoga Wood as a limit to its opinion's broad application. ${ }^{70}$ However, the Court only narrowly discussed the characteristics that make a corporation "closely held"; this narrow discussion enabled the Court to assert that it seemed "unlikely that the sort of [large, publicly traded] corporate giants to which HHS refers will often assert RFRA claims." 71

As "corporate giant" and "closely held" are not mutually exclusive terms, this statement is only accurate if the Justices imagine that some salient difference exists that might distinguish a corporation as "Hobby Lobby close" from close in a way that would cause an inappropriate result. Thus, something must motivate the assumption that the rule articulated in Hobby Lobby will transform when extended to the depersonalized behemoths (S.C. Johnson, for example) that are closely held in ways that may be legally indistinguishable from Hobby Lobby Stores and Conestoga Wood. This must be so, even though the giant corporations bear no trace of the characteristics motivating the Court's sympathy in the initial case. The implication is that the Justices, while not articulating such a belief, must assume some sort of dividing line between these different iterations of what are, definitionally, "close companies." What is the nature of that line?

The corporation more amenable to Hobby Lobby closeness would seem to be more a product of human social norms. This type of corporation is, to the Court, more legitimately treated as human, blurring the relevance of any distinction between various types of person. The corporation is thus quite summarily treated much as a human individual might.

For good or ill, rhetorical imprecision is the device by which the law is changed even while judges gesture to the confines of stare decisis. ${ }^{72}$ It is a mechanism that appears to be operant in the development

70. Burwell, 134 S. Ct. at 2765.

71. Id. at 2774. In fact, whether they saw the case as correctly or incorrectly decided, commentators were quick to realize that the imprecision of the opinion opened the possibility of asserting religious claims to a wide variety of corporations, including entities little resembling Conestoga or even Hobby Lobby, and perhaps having even greater effects on the rights of dissenting others.

72. On indeterminacy of legal language, see RichARD A. POSNER, HOW JUDGES THINK (reprt. ed. 2010); Ronald Dworkin, Law as Interpretation, 9 CRITICAL INQUIRY 179 (1982); Stanley Fish, Working on the Chain Gang: Interpretation in Law and Literature, 60 TEX. L. REV. 551 (1981); 
of both the campaign finance jurisprudence embodied in Citizens United and the RFRA jurisprudence of Hobby Lobby.

In both Carnell and Hobby Lobby, we see the development of an image of the corporation as made up somehow of the people underlying it and simultaneously taking on some kind of status from the corporation as entity. Neither case makes sense under only one or the other of these theories; instead, the arguments depend on the ability to hold entity and aggregate stances simultaneously. The people underlying the corporation are what the rights of the corporation arise from; yet, they cannot claim this right except in reference to the corporation as entity. The corporate entity cannot be said to hold the human-ish characteristic claimed by the underlying people to need protection - the right can, however, be read in if one can imagine the corporation as aggregate. Entity status affords the corporation the tenor of individual personhood, and aggregate status imparts personal attributes, distinctions between human and corporate personal rights become more difficult to maintain.

An example may help illustrate this situation. A crucial point for the analysis of a free-exercise claim is "belief": "[A]bsent religious belief the Free Exercise Clause is without application." order for such a claim to prevail as asserted by the corporation, either the corporation must "believe" (under an entity theory) or what are considered the corporation's "beliefs" must be the beliefs of some individual or individuals associated with it (under a very loose aggregate theory). However, as the mandate cases made their way through the courts, neither of these two views appeared especially promising. On the other hand, we might reject wholesale the ability of corporations to raise any such claim, asserting that corporations, "[b]eing only creatures of positive law with defined and limited powers," must necessarily "lack a spiritual element." 74

The horns of this dilemma are hardly new, nor are attempts to reconcile them. ${ }^{75}$ Indeed, such efforts once dominated American debates on the nature and responsibilities of the corporation-especially in response

Stanley Fish, The Law Wishes to Have a Formal Existence, in THERE's No SUCH THING AS FREE SPEECH: AND IT's A GoOD THING ToO 141 (1994); Dewey, supra note 47.

73. Rutledge, supra note 58, at 25; see discussion supra note 67 and accompanying text.

74. Rutledge, supra note 58 , at 28 . Unless we were able somehow to concatenate the corporation-as-entity to the "soul" of the aggregate of people who made it up (and who, we might stress, would be forced to forfeit these rights if this claim may not be asserted in the name of the corporation, a claim as debatable as it is powerfully sympathetic - and one voiced across the political spectrum).

75. See, e.g., Margaret M. Blair \& Elizabeth Pollman, The Derivative Nature of Corporate Constitutional Rights, 56 WM. \& MARY L. REV. 1673 (2015). 
to the Great Depression. The next subpart reviews this discussion and considers the implications of its correspondence to contemporary debates.

\section{B. Solidarity and Disintegration in the Nature of the Corporation}

As the Great Depression raged in the 1930s, and in its wake, as people tried to figure out what had gone wrong and how to fix it, American thinkers began to take up the insights from the corporatist ideas current in Europe. ${ }^{76}$ Corporatism describes a strand of social theory that imagined as ideal a system of centrally-planned, overlapping, hierarchical corporations - social organizations whose raison d'etre was the ordering of society, not the market. ${ }^{77}$

The Contingent Corporation is strikingly consistent with these corporatist conceptions. What is most salient for the Contingent Corporation is, in fact, its emergent group properties-whether we characterize these as moral, spiritual, cultural, or something else in nature. The key is the conception of the corporation as effervescing from and feeding the preferences of the people underlying - not just making up - the group. This compatibility of the Contingent Corporation with a corporatist perspective is significant because it suggests a capacity for the corporation as necessarily implicated in societal expectations and outcomes.

Indeed, writing just before the recent financial crisis, William Bratton and Michael Wachter predicted the impending arrival of a new era for corporatism. ${ }^{78}$ Bratton and Wachter's position makes sense on a number of levels. For example, great similarity exists as to the proximity to crisis between today and the years following the Great Depression. Today's popular political desire for change in the business corporation's legal and social status also appears to be similar to that experienced after the Great Depression. Regardless of the distribution of discomfiture with the corporation's privileges, the corporation's proper place in society is currently, as then, a conspicuously open question. This comparison is not to say that the current moment signals some full-throated return of the popularity of corporatism. It is not much of a stretch, however, to suggest that the central questions and concerns undergirding both the Supreme Court's reasoning in the Contingent Corporation cases and my own anal-

76. See generally William W. Bratton \& Michael L. Wachter, Shareholder Primacy's Corporatist Origins: Adolf Berle and The Modern Corporation, 34 J. CORP. L. 99 (2008).

77. Romano, supra note 36, at 937 n.41 (referencing Adolf A. Berle, Power Without Property 2-3, 8 (1959); and Adolf Berle \& Gardiner Means, The Modern Corporation AND PRIVATE PRopriety 356 (1932)).

78. See Bratton \& Wachter, supra note 76. 
ysis of the Māori-owned corporation bear some resemblance to those that undergirded early twentieth-century corporatist thought.

Illustrative here is the changing tenor of the work of Adolf Berle in regard to these issues. While Berle's work has long been taken to champion the idea of shareholder primacy, he spent the middle and later parts of his career outlining the ways in which corporations ought to be intertwined with community norms. ${ }^{79}$ Having been made a patron saint of shareholder primacy and of law and economics methodologies in the theorization of the corporation over the past century, Berle's work provides a provocative commentary on the attribution of personal or communal characteristics to corporations in a time with important similarities to our own.

Roberta Romano links Berle's corporatist ideals directly to his view of the role of management as "that of a disinterested public servant, a role that could provide the social stability necessary for the attainment of the corporatist ideal." 80 Part of the manager's role was to incorporate the diverse views of four distinct constituencies - "suppliers, customers, employees, and the outside community"-into something stable, even if not necessarily harmonic. ${ }^{81}$

And yet, a type of spiritualism seen as common to corporatist thought is here as well - not in any explicit theory of group cohesion, but bound up within the idea of the corporation. ${ }^{82}$ As with the corporatist views that prevailed in Europe, Berle's vision was suffused with spiritual or religious tropes, with the corporation acting as "systemic glue" for its constituent parts, as "collective soul" and societal "conscience-carrier." 83 The end result is that, just as in other visions of corporatism, the determination of the best path for business - and for society - is left to managers: the manager becomes "the oracle of the public interest." 84

The corporatist vision generally appears to model the corporation as a structure naturally able to carry, or needing to carry, within it some kind of conscience. ${ }^{85}$ It is a vision that also seems naturally aligned with

79. See id.

80. Romano, supra note 36, at 937 (referencing AdOLF A. Berle, POWER Without Property 2-3, 8 (1959); and Adolf A. Berle \& Gardiner Means, The Modern Corporation And PRIVATE PROPERTY 356 (1932)).

81. Romano, supra note 36 , at $936-37$.

82. See id. at 937. (1955)).

83. Id. (quoting Adolf A. Berle, The Twentieth Century Capitalist Revolution 148

84. Id. at 938 .

85. But considerable ease and danger exist in conflating "religious," "conscientious," and "socially responsible" behavior. 
the vision of the corporation expressed by Justice Alito in Hobby Lobby. But what is missing in this reading of Berle's corporatism is attention to what might have made this vision of corporate control plausible at the time- that is to say, its regulatory and social context. ${ }^{86}$ With the image of corporate law as public law that prevailed at the time, and with it the general idea that a main point of corporations was their public benefit, Berle's imagery and his imagining of a constitutionally, socially responsible corporation makes sense-but not without that specific historical and regulatory context.

In Berle's corporatism, this group-ontology is meant to be embodied in the managers; managers instill in the corporation a group-spirit that itself comes from the larger society. Berle does not theorize the formation, the movement, or the terms of this group ontology-what we might call "solidarity." To understand the nature of these processes, we look to the classic work of Émile Durkheim, another luminary of the social theorization of corporate groups.

Just as corporatist visions of the group raise questions of "conscience," so too do they elicit consideration of solidarity. Both internal regulation of mores and behavior by the members of the group, and external regulation by the state are necessary to describe the solidarity of the group - a necessary alchemy most clearly expressed in Durkheim's work on solidarity and the division of labor. ${ }^{87}$ In Durkheim's view, such solidarity requires conflict. His focus is upon ways to get at this relationship empirically (what does the group think) and upon describing its recursive nature (how does it come to think). Groups in this conceptualization are not so much entities as ongoing processes; their existence arises out of, is dependent upon, and may be described by, a state of tension between mechanical togetherness and organic entropy. Instead of contradicting or negating each other, each becomes the condition for the other. Durkheim's work is relevant here because it represents a seminal effort to describe the genesis and continuation of a group in this processual way.

Durkheim's first movement in this model is to argue that internal moralities better regulate complex groups than do externally imposed laws. In this estimation, complex groups must be spontaneously regulated: regulation from on high will fail to capture the complications and

86. See, e.g., Morton J. Horwitz, Santa Clara Revisited: The Development of Corporate Theory, 88 W. VA. L. REV. 173, 173 (1985); Millon, supra note 48; Bratton \& Wachter, supra note 76, at 100 .

87. See generally ÉMILE DURKHEIM, THE Division of LABOR IN SOCIETY (W.D. Halls trans., 1997) (1893). 
various forms of internal knowledge that are the hallmark of complexity. What really and effectively governs the group is solidarity ${ }^{88}$ specifically, a form of organic solidarity that emerges spontaneously and internally; a form that contains, rather than quashes, the group's ever-moving equilibrium, containing intact all oppositions inside it. The same holds for power inequalities: freedom lies in the expression of "precisely natural inequalities." 89 No external modulator should interfere, because - so long as there is "absolute equality in the external conditions of the struggle"- the powers will push against one another so as to come round right. ${ }^{90}$ This result, predicts Durkheim, will not be anarchy but an ordered and naturally regulated expression of "true worth." "He thus advises against the external imposition of heavy and restrictive regulation.

Yet, how, then, does one move from these internal conventions to the regulation of in-group acts and relationships affecting out-group interests? After all, what Durkheim describes here sounds like a prescription for fragmentary, particular moralities, each rationalizing its actions to external queries by means of an internal logic. Ultimately, however, Durkheim will complicate this seemingly direct proposition.

Each type of legal rule is "accompanied by a set of rules that are purely moral." 92 Penal law comes with a morality in common. Restitutory laws travel with little sets of moralities - one for each profession governed. ${ }^{93}$ But even where it looks as though society is spinning off into a million discrete moralities - to each group its own species of morals-plus-laws - this dispersal is restrained by another morality that keeps them together: "[e]very society is a moral society," and each is united with a moral bond. ${ }^{94}$ Were this not so, we would be describing not a society but a mass of ever out-whirling fragments. Everywhere we look there is a separation, and everywhere a binding-together.

88. Id. at 302; see also Romano, supra note 36, at 929-30, 935 ("Indeed, the spiritualism of an organic community is a central element in the corporatist vision. It binds the functionally specialized parts into a greater whole, ensuring the harmony of the system. The overriding goal is the destruction of politics, that is, the absorption of the political realm into the social, to achieve a unified societystate, free of divisive conflict among groups.").

89. DURKHEIM, supra note 87 , at 313.

90. Id.

91. Id.

92. Id. at 172 .

93. The concept of such self-governing moral spheres is, of course, more complicated than this description.

94. DURKHEIM, supra note 87, at 173. 
It is in this manner that Durkheim's Corporations ${ }^{95}$ were to act as a societal corrective. These groups were to be left to their own internal orders because they had consciences, morals, or perhaps beliefs, that: rendered them worthy of our trust that they would regulate themselves in morally "good" ways; and made competent external regulation of the group's behavior both difficult and unnecessary.

A common morality in the face of heterogeneous bits would be their hallmark - a morality arising not by fiat or by vote, but organically. ${ }^{96}$ Thus, despite opposition, Durkheim argued that the corporation's heterogeneity in fact compelled it to be profoundly and constitutionally moral. $^{97}$

Having done this, however, Durkheim does a seeming about-face. He notes that leaving groups to their own moral devices, and thereby letting each have its little duchy, will not result in individual freedom. "[I]t so happens," Durkheim states (with an almost audible clearing-of-throat), "that liberty itself is the product of regulation." 98 According to Durkheim, relations in organic societies are increasingly modulated by means of restitutory rules. These may be positive rules dictating cooperation or rules giving rise to rights, both real and personal, that separate members' interests in things. This set of juxtaposed rights gives individuals space and restrains the intrusion of one individual's exercise of his freedoms into the freedoms of another. It keeps disputes from atomizing a society: good fences make good neighbors. This is negative solidarity- "not a true solidarity, but rather the negative aspects of every type of solidarity," 99 an apparently necessary mirror image of organic solidarity.

What Durkheim's work reveals is the simultaneous difficulty and necessity of holding two views of regulation - and implicitly, two views of groupness - in tension. What comes first, the regulation-shunning, internally- and morally-ordered egg, or the law-loving chicken?

The first condition for an entity to become coherent is for the parts that form it not to clash discordantly. But such an external harmony does not bring about cohesion. On the contrary, it presumes it. Negative solidarity is only possible where another kind is present, positive in nature, of which it is both the result and the condition. ${ }^{100}$

95. In this subpart I use the proper noun "Corporation" to refer specifically to Durkheim's ideal-typical corporation.

96. In both the modern sense and in Durkheim's "organism" sense, this morality-heterogeneity synergism applies.

97. DURKHEIM, supra note 87 , at xlvi.

98. Id. at 320 .

99. Id. at 75 .

100. Id. 
The legalistic chicken and the friendly egg continuously reposition themselves, and this eternal repositioning is necessary. This means that what looked like an aversion to regulation for Durkheim is actually an embrace of it as crucial. The markets should not be left completely to their own devices: a deficit in discipline surely leads to moral erosion. ${ }^{101}$ Regulations and moralities are thus wound up into each other.

If we take the chicken-and-egg nature of regulation and freedom to typify the conditions of the production of solidarity and cohesion within the modern corporation, what is cohering? What, in other words, is the shape of the entity thus formed, and who is included as making up that entity? Further, what does that mean for the nature of the corporation? At first glance, Durkheim appears to hold an image of group formation that is identical to Romano's European societal corporatists ${ }^{102}$ - but this is not so. According to Romano, an abiding feature of these corporatist views of group formation is that the harmony of the corporate group arises because "discordant interests are quelled by the development of communal ties." ${ }^{103}$ Romano contrasts European societal corporatisms with that of Berle, using Huntington to buttress the claim that the atypical form taken by Berle's corporatism (which, unlike Continental corporatisms, did not focus on corporatism as vanquisher of disharmony) was the result of the peculiar character of American nationalism. This American exceptionalism, Romano argued, "takes the form of a civil religion expressed in political, rather than cultural or territorial, ideals." 104 But this "corporatis $[\mathrm{m}]$ in the American grain" compares more closely to the continental corporatism of Durkheim with its necessitation of conflict. ${ }^{105}$

Adolf Berle's corporatism started out resembling that of Durkheim and, in later years, it only becomes more so. As in earlier times, Berle expects managers to hold within the corporation a function fundamentally shaped by a concern for the good of society, ${ }^{106}$ positing a self-evident link between corporate effect on society and corporation as "social institution," not one that is "private." This link was sufficiently self-evident to allow Berle to say, in 1968, that the "[t]ransition of the large corporation from a private enterprise to a social institution has now been accom-

101. See id. at xxxiv.

102. Romano, supra note 36, at 935.

103. Id. at $935,934-38$.

104. Id. at 938 (referencing SAmuel P. Huntington, American Politics: The Promise of DISHARMONY 23-25 (1982)).

105. Id.

106. See generally Adolf A. Berle, Corporate Decision-Making and Social Control, 24 BuS. LAW. 149 (1968). 
plished and is generally recognized." 107 Berle does not mean "social institution" in the warm, fuzzy sense of today's discourse on "corporate social responsibility." He uses this term instead to refer to the overwhelming power of corporations and the sheer size of their effect on society, as well as the pure necessity, as a result, that they not be left to their own devices. ${ }^{108}$

Berle further emphasizes the necessity of close and active state and societal oversight. ${ }^{109}$ The shape of society and the form that a good society ought to take are, he stresses, necessarily the domain of these entities, not corporate structures:

The corporate system of our time can do whatever in reason is asked of it in terms of production, expenditure of capital and distribution of profit. But the corporate system cannot, should not and should not be expected to produce a society. It can and should conform to social requirements; it can and should lend help to government and to quasi-public and other institutions whose task is to develop a society both good and just. On the other hand, nothing in the structure of corporations or the training of their management entitles them to be philosophers. ${ }^{110}$

107. Id. at 149 .

108. See id. at 151 ("[W]e have huge and growing corporations whose operations are unlimited in direction and scope, required by law to have a certain competitive aspect, but permitted to have, in fact, a high degree of power over the development of the country's economics. Social responsibility is the result of this dichotomy.").

109. See id. at 150 ("Some thirty years ago, I debated [the extent and the importance of corporate responsibilities for wider societal interests] with the late Professor E. Merrick Dodd, of Harvard. I maintained that corporate managements were primarily trustees for stockholders. He insisted that they were trustees not only for stockholders but also for their labor, their customers and the area of business on which they had impact. Pragmatically, Professor Dodd won the debate.”).

110. Id. at 152. The passage in full is electric:

The corporate system of our time can do whatever in reason is asked of it in terms of production, expenditure of capital and distribution of profit. But the corporate system cannot, should not and should not be expected to produce a society. It can and should conform to social requirements; it can and should lend help to government and to quasi-public and other institutions whose task is to develop a society both good and just. On the other hand, nothing in the structure of corporations or the training of their management entitles them to be philosophers. They can be held (as they were two generations ago) to an obligation not to resist demands for betterment. They should be required to assist the social evolution as a democracy pounds out social principles, and as growing density of population requires more rules of the road. Individuals, including those active in the corporate world as also individuals engaged in academics, politics and government can propose standards and measures and can campaign for them. Corporations can favor and protect their personnel in doing so. They can urge that better principles shall prevail and that better road rules shall be made. They can even offer technical assistance in these processes. But there they must stop. Beyond that it seems to me they are subjects. Nothing in their 
Commenting, supremely drolly, on the role of regulation (specifically, here, antitrust regulation) in economic life, he notes: "Factually, left to itself, the free market would not long exist." "111 Berle's corporatist vision thus appears here to have shifted - slightly but significantly - to resemble that of Durkheim, stressing the necessity of controls external to the corporation - state, society - in addition to internal mores oriented toward supporting, or at least not "resisting," those external ones. ${ }^{112}$ In Berle's later corporatist vision, as in Durkheim's early one, internal community and external regulatory forces work necessarily in concert to turn corporate behavior in the direction of the social weal. In the eyes of both, the regulatory environment is part of the alchemy of a corporation's conscience and its solidarity - its personality.

The following Part analyzes ethnographically how the interaction of law and group norms described by Berle and Durkheim arises in a real-life situation to shape the way a corporation is ascribed personal attributes.

\section{A MĀORI-OWNED CORPORATION AND A MĀORI CORPORATION}

What makes a Christian corporation a Christian corporation? Or a Black corporation a Black corporation? The answer to these questions may resemble the answer to a similar sounding question that emerged in New Zealand and to which I turn in this Part: what makes a Māori corporation a Māori corporation, as opposed to a Māori-owned corporation? Part II described the lacunae the courts have left us with in determining what characteristics should be considered in future cases, and tendered two models of processes important in this determination. This Part of the Article describes the dynamics of cultural identification in the case of the New Zealand Māori-owned "Māori incorporation," with the ways that, in the Contingent Corporation cases, corporations came to be adjudged to have political opinions, racial identities, and religious beliefs. I illustrate my argument by reference to examples drawn from my ethnographic research on Māori-owned corporations. This ethnographic data brings into view the processes by which cultural affiliations may be ascribed to corporations. In other words, I examine what the

present situation entitles them to govern, and if they try to take on that role, they are headed for trouble.

Id.

111. Id. at 151.

112. See id. at 152 .

113. While in the United States "incorporation" describes a process rather than a classification, the term's usage in respect to the New Zealand Māori incorporation captures both of these aspects. See TTWMLA, infra note 115, § 247. 
"Māori-ness" of Māori corporations can tell us about similar debates regarding personal attributes of corporations more broadly.

Much in the way that there is no unitary, frozen "Māori Culture," there is no such thing as a stable, categorical "Māori Corporation." If, as I argue, there is something that might be called a Māori Corporation, it obtains that identity from some other source than the unilateral fiat of some powerful shareholder or management interest. Relatedly, while the law brings into being something called the "Māori incorporation," this alone does not give the corporation some Māori identity cut from whole cloth. The Māori corporation is formed through the contingent, shifting interactions between Māori and non-Māori people, Māori histories, Māori-owned land, and the law of corporations; it is formed, that is, by means of a Durkheimian rendezvous between chicken and egg.

\section{A. The Indigenously Owned Corporation and the Indigenous Corporation}

At the northern end of New Zealand's South Island, in a little city called Nelson, sit the headquarters for a corporation, Wakatū Incorporation, owned by Māori people of the area. A few years ago I was working in those headquarters with a friend of mine, a Māori man who is the general manager of Wakatū. He daydreamed aloud to me about the future of his people and the business they owned. The corporation is a land-development company whose shareholders are members of four Māori tribes; my friend, Ropata, is one of its shareholders. We were planning a drafting session for the corporation's long-term business plan, putting together briefing materials for the people who would be doing the drafting: projections of population, of pressing issues for the corporation (risks, for example, and burgeoning opportunities), of future industriesdiverse industries, but based, always, in the land of the area and its shores - and of different indicia for measuring progress on each front.

In our planning meetings, every parameter we discussed as crucial to the corporation's economic success was simultaneously and multiply framed in terms of the mana - the esteem, influence, or renown - of the shareholders of the corporation and their extended families. ${ }^{114}$ Legislation defines a Māori person as "a person of the Māori race of New Zealand" and "a descendant of any such a person." 115 But in Māori eyes, the operant idea is not the mere technical existence of such descent but the

114. We are going to get a bit metaphysical here. Trust me; I'm an anthropologist.

115. Te Ture Whenua Māori Act/Māori Land Act $§ 41993$ (N.Z.) [hereinafter TTWMLA], available at $\mathrm{http}: / / w w w . l e g i s l a t i o n . g o v t . n z /$ act/public/1993/0004/latest/DLM289897.html. 
practice of whakapapa, genealogy: if you can recite your lineage back to a Māori ancestor, you are Māori. The people involved with Wakatū, from management to shareholders to employees, utilize the history of the ancestors of the tribes from which the shareholders hail in order to assert links of kinship between the whanau (the shareholders and their extended families) and the corporation. For Ropata, and for many of my interlocutors, Wakatū is a corporation grown from the ground that holds the bones buried here of generations past, and from which generations to come will grow. These bones were the skeleton on which the body of the organization was built, a body that was supported by the weaving of literal genealogical links between the corporation, the shareholders and their extended families, their ancestors, and the land. The long-term business plan looked to genealogical ties to suggest plans for a corporate body that extended out to the shareholders of generations past and generations to come. This, by the way, was a business plan for the next five hundred years.

Wakatū is indeed a very particular sort of corporation, but it is not the only form a Māori-owned corporation might take. Although the term holds multiple meanings, what might be termed "Māori Companies" are generally regarded as Māori companies due either to their claiming the title or through the bare fact that the majority of their owners are Māori people or entities such as tribes, subtribes, or other Māori corporations. ${ }^{116}$ These types of Māori companies are Māori businesses registered under the 1993 Companies Act — what might be considered the general legislation for business associations - and have the same duties and responsibilities as any other New Zealand company founded under that Act. ${ }^{117}$

But the characteristics that make forming a "Māori Company" a practical option for specific types of Māori business present a certain set of difficulties for other types of business. The structures and politics of tribes and subtribes are sometimes incompatible with the individually

116. See generally Mason Durie, Universal Provision, Indigeneity and the Treaty of Waitangi, in Roles AND PERSPECTIVES IN THE LAW: ESSAYS IN HONOUR OF SiR IVOR RICHARDSON 167 (David Carter \& Matthew Palmer eds., 2002); GARTH HARMSWORTH, REPORT ON THE INCORPORATION of TRAditional VAlues/TikANGa INTO CONTEMPORARY MĀORI BuSINESS ORgANISATION AND PROCESS (2005), available at http://citeseerx.ist.psu.edu/viewdoc/download?doi=10.1.1.452.7226 \&rep=rep1\&type=pdf; HeI WHAKATINANA I TE TŪRUA PŌ, BusinesS SUCCESS AND MĀORI Organisational Governance Management Study (2003); Te Puni KōKiri, The Māori ECONOMY (2012), available at http://www.tpk.govt.nz/en/a-matou-mohiotanga/business-andeconomics/the-maori-economy. From this point on in the Article, I use the term "company" to indicate business associations under the ambit of the Companies Act.

117. Companies Act 1993, Public Act No. 105 (N.Z.); see also Te Puni Kōkiri, Whakamahia: Support, Information, and Opportunities (July 11, 2014), www.tpk.govt.nz/mi/whakamahia/ effective-governance/what-is-governance/company/. 
focused nature of corporate shareholding. Even setting aside the focus upon individually determined benefits generally integral to the structure of stock companies, cultural or societal priorities might still go unrecognized in the context of the company. These issues will loom large for groups whose main asset base is communally owned Māori land. The people who are of the tribes and subtribes affiliated with that land, or whose families have owned that land or had traditional authority over it for generations, might have particular feelings about its management. If they were to incorporate their interests in this land, the corporation's shareholders - the land's erstwhile owners - might prefer to think of themselves as owners of land rather than merely of shares of stock. Further, they might not look kindly upon managers taking risks - even merely the risks common to business - that might lead to the loss of land; and they might disapprove of management taking on operations that would affiliate the people underlying the company with unsavory business dealings. Having tribes or subtribes - communal groups with strongly felt social priorities - as shareholders might present still other difficulties.

In acknowledgement of these types of Māori interests, the Māori Land Act articulates pronounced concern with how land communally owned by Māori ought to be protected from alienation (and thus the government protected from further shame). Thus, New Zealand has a set of institutions in place for the incorporation of interests in such land. These institutions include a variety of types of organizations primarily under the ambit of the Te Ture Whenau Māori/Māori Land Act 1993 (TTWMLA or Māori Land Act). Passed in the wake of an enormous settlement relating to Māori grievances with the Crown, and the sudden attention this settlement brought to Māori land and money, ${ }^{118}$ the Māori Land Act clarified the obligations and distinctions of the land-based "Māori incorporation," as well as a variety of types of land-based trusts. ${ }^{119}$ It also promulgated protections meant to address the idiosyncra-

118. This settlement was the 1992 "Sealord settlement," which compensated Māori people for the government's breaches of the Treaty of Waitangi in constructing its fisheries conservation scheme.

119. TTWMLA, supra note 115, §§ 246-284. The trusts under the 1993 Māori Land ActMāori Land Court Trusts - tend to differ from Māori incorporations in a number of ways, but most particularly in their (relative) unsuitability for high risk/high reward business. There are several types of these trusts; out of all of these, the variety called the Ahu Whenua trust is the most amenable to commerce. Like all of the Māori Land Court Trusts, however, Ahu Whenua are quite limited in terms of their risk-taking, management, and alienation of land. Id. §210-221. For instance, despite their restriction in contrast to Companies Act enterprises, Māori incorporations do have considerable freedom to exercise their business judgment. The law requires greater duty of care on the part of trustees, a demand that will necessarily make the trust form less suited to risky (and thus putatively very profitable) ventures. $I d$. $\S 223$. Māori incorporations, on the other hand, are encouraged to 
sies I have described with regard to communal land ownership. The Māori Land Court has a close rein on all of these land-based entities, and the beneficiaries or shareholders (who, specifically for the reasons I outlined above, are generally called "owners") are extremely involved in the way each is run. ${ }^{120}$

Although they have more freedom to undertake commercial activities than do the trusts founded under TTWMLA, Māori incorporations like Wakatū are nonetheless very closely regulated in terms of what they can do with Māori-owned land. ${ }^{121}$ As is the case with all of these TTWMLA organizations, the protections put into place by the Act to secure the interests of the beneficial owners of Māori land against alienation make it more difficult for boards to secure approval for the sale of land and (not altogether coincidentally) more difficult to conduct business at a profit. Among other restrictions, the Māori incorporation must hold on to a certain amount of land at all times, and in order to sell any portion of Māori land, the board must gain approval for the sale by a special resolution passed by those holding 75 percent of the incorporation's shares. ${ }^{122}$

There are other external pressures placed on the directors and the management in terms of fiduciary expectations. In contrast to duties of directors of other companies, the duties of directors of Māori incorporations (and the courts' standards for the determination of the breach of those duties) are remarkably vague. ${ }^{123}$ The Act's primary priority is to limit the alienation of Māori land; ${ }^{124}$ there is an argument that might be made that the provisions for directors' responsibilities, and the courts'

take on at least moderate risk; bad outcomes of this behavior do not subject the incorporation to actions in breach of trust: "No Māori incorporation acting in accordance with its powers and in compliance with this Act or any other Act shall be in breach of trust." Id. $\S 250(5)$.

120. See, e.g., id. $\S \S 151-68,246-84$.

121. Consonant with the focus of most New Zealand business, Māori enterprise tends to concentrate mainly on primary production-forestry, agriculture, fishing, and land management. TE PUNI KŌKIRI, ANNUAL REPORT: FOR YEAR ENDED 30 JUNE 2015, at 33 (2005), available at www.tpk.govt.nz/mi/a-matou-mohiotanga/. This is especially true of Māori incorporations: while it is not strictly required by law, their operations will concentrate on land-based activities as their asset bases are generally focused on land that they cannot easily exchange for other assets. As a result of the Sealord settlement, see supra note 118 and accompanying text, and the vesting in Māori of fishing quota, some Māori businesses are also well placed to involve themselves in seafood enterprises of various types. Wakatū, for instance, has on several occasions partnered with the Sealord Company (which remains under Māori ownership) to undertake fishery ventures.

122. TTWMLA, supra note $119, \S 150 \mathrm{~B}$.

123. See Companies Act, Public Act No. 105, § 128; TTWMLA, supra note 115, § 269; see also Opawa Rangitoto 2C Incorporation [2004] NZMLC 53; Bramley v Hiruharama ponui Inc Committee of Management [2006] NZMAC 27.

124. TTWMLA, supra note $115, \S 2$. 
explication of their breach, are so vague precisely because the Māori Land Court has such an involved role in the conduct of Māori incorporations. In addition to being involved with directors' decisions regarding land use, the court has enormous freedom to choose and replace directors; ${ }^{125}$ the close, but capricious, scrutiny by the courts might explain Māori incorporation directors' propriety in terms of seeking shareholder approval for incorporations' ventures.

Māori corporations under the 1993 Companies Act (standard companies owned by Māori) and Māori corporations under the Māori Land Act (Māori incorporations) are separate legal entities from their shareholders, entities with a putatively perpetual lifespan. Despite this similarity, however, there are some slight but important differences in the temporal orientations of the two. That directors' obligations under the Companies Act are laid out in detail does not necessarily result in restraining company directors more than Māori Land Act corporation directors; instead, the Companies Act restrictions act as a long leash, giving Companies Act directors considerably more freedom to take risks than have Māori Land Act directors. This means that, speaking even merely in terms of legal structuring, the focus of the Māori incorporation will tend to be much more long-term than that of the company.

The protective posture the government takes against the alienation of Māori land means that those whose main asset is communally owned Māori land, and who wish to form a commercial corporation, will necessarily form a Māori incorporation. In addition to protecting Māori land from alienation (which would include shielding it from risky ventures), one of the primary purposes underlying the conduct of the Māori incorporation is to allow some commercial flexibility (that is to say, risk). Māori incorporations can risk more of their assets than trusts can. As compared against other entities formed over Māori land, the Māori incorporation is a veritable capitalist playground.

Māori incorporations thus constantly negotiate-and I argue, are constituted by - this balancing act between profit and social responsibility. The varied ways in which New Zealanders understand this concatenation of freedoms and protections give rise to an ideation of the relationship between the corporation and the land not as one of mere management for profit, but as guardianship of the land. ${ }^{126}$ The meaning of this role is constantly debated among directors, managers, employees,

125. Id. $\S 269,280$.

126. Gwendolyn Gordon, Whanaungatanga: We Are a Family Business, in Bones, Breath, Body: The Life of an Indigenously Owned Corporation 162 (Nov. 4, 2013) (unpublished manuscript) (on file with author). 
shareholders, and other stakeholders alike. To what extent should the corporation be responsible for the economic, social, and cultural development of its shareholders and their extended families, or of Māori people in general (or even more generally, the well-being of society)? What forms should that responsibility take? What is the shape of the constituencies to which the corporation is responsible? ${ }^{127}$

The ways in which Māori commercial activity and its relation to indigenous authenticity are imagined in New Zealand society are important factors in the institution of the legal and economic changes I have described and in the outcomes of these changes for Māori people. For the Māori incorporation, perceptions of legitimacy rest on what looks like a paradox: to be successful, these corporations need to be "fully corporate," yet simultaneously "authentically traditional." By "fully corporate," I mean that these organizations work against a background of high-profile Māori business failures commonly read as indications that Māori are bad at business; against a supposition that Māori political complexities hobble Māori enterprise from the outset; against, that is, a suspicion "that tribal politics interferes with market efficiency." 128 In the face of this settler nation's "structures of expectation" 129 regarding the incompatibility of indigeniety and capitalist enterprise, Māori businesses must be exceedingly careful to project an image of prudence and professionalism. By "authentically traditional," I mean that Māori involved with running businesses also fight a supposition that engagement with capitalist enterprise disqualifies or at least reduces them in terms of Māori identity. ${ }^{130}$ Whether they are very successful or less so, Māori companies must constantly negotiate this needle's eye of inside and outside, difference and similarity.

\section{B. The Indigenous Corporation and the Contingent Corporation}

Carnell and Hobby Lobby build upon Citizens United's simplification of the analysis of corporate rights. In these cases, the corporation

127. Gwendolyn Gordon, Introduction: Agnostic Anthropologies of the Corporation, in Bones, Breath, Body: The Life of an Indigenously Owned Corporation 3 (unpublished manuscript) (on file with author).

128. Jessica R. Cattelino, One Hamburger at a Time: Revisiting the State-Society Divide with the Seminole Tribe of Florida and Hard Rock International, 52 CURRENT ANTHROPOLOGY S137, S142 (2011).

129. Jessica R. Cattelino, The Double Bind of American Indian Need-Based Sovereignty, 25 Cultural ANTHROPOlOGY 235, 235 (2010).

130. See, e.g., Elizabeth Rata, Encircling the Commons: Neotribal Capitalism in New Zealand Since 2000, 11 Anthropological Theory 327, 327-53 (2011); Annette Sykes, Bruce Jesson Foundation Lecture: The Politics of the Brown Table, (Oct. 19, 2010), available at http://news.tangatawhenua.com/wp-content/uploads/2010/11/Annette_Sykes_Lecture_2010.pdf. 
begins to resemble the corporatist conception of the corporation's nature popular at the beginning of the last century. Missing, however, and severing the resemblance, is that the new analysis lacks the thoughtfulness and attention to social consequences of the previous one. This omission arises directly from the simplification of the analysis the court embraces.

Zephyr Teachout has argued that the notions of corporate free speech and group decision-making - as demonstrated in the reasoning of the Citizens United opinion-came into being out of the disjuncture between the last-century Court's attentiveness to wriggly, messy, real-life issues in cases and the modern Court's concern with bright-line rules. ${ }^{131}$ It is, perhaps, an inverse iron cage: the modern Court keeps the rhetorical trappings of the past but discards the attentiveness to context and contingency to link this past to lived life. ${ }^{132}$ In a similar light, I suggest that these new, socially complex developments in corporate law, with the societal stakes that are becoming apparent, entreat scholars to ask the kinds of questions that can engage this more complex notion of culture.

How might analysis like that modeled in the previous Part change our way of examining corporations - and of imagining the corporation as a rights-holder? The parallels between the Māori incorporation and the idea of the corporation elaborated in Carnell and Hobby Lobby may not be immediately apparent, but they are there nonetheless. The leaders of the Māori incorporation, tasked with the stewardship of Māori-owned land, will necessarily negotiate the corporation's status with regard to its indigenous shareholders and the often culturally important land that is the center of their asset base - that is, they will negotiate the corporation's cultural identity. The Māori incorporation thus bears more than a passing resemblance to the Contingent Corporation.

What makes the Wakatu 500 -year business plan thinkable is the idea of the corporate body as somehow coterminous with a particular set of tribes and their history, or with a set of values extending down through the tribes' histories. During the year and a half I spent interviewing, shadowing, and becoming involved in the lives of the managers, board members, and shareholders of the corporation, the importance of a certain set of questions became clear: for example, questions of what "self-

131. See generally Zephyr Teachout, The Historical Roots of Citizens United v. FEC: How Anarchists and Academics Accidentally Created Corporate Speech Rights, 5 HARV. L. \& POL'Y REV. 163 (2011).

132. "Reading the corruption and political speech cases of the mid-twentieth century is like watching a shawl gradually fall off of a woman's shoulders onto the floor during a concert. The old ideas about corruption are not so much thrown out as misplaced and then forgotten - such that by the time the twenty-first century comes around, and the shawl is again needed, one doesn't even know where to begin to look." Id. at 166 . 
image" the whanau - the corporation's shareholders and their extended family - projects upon the corporation when the two are, discursively, made coterminous; and questions of how images of the model whanaumember-its responsibilities, its rights, its connection to land-get wrapped up in management's ideation and presentation of the corporation to the public at large, and are then projected back to the whannau. The histories, stories, legends, and sayings deepen or limit the relationship between the corporation and the tribes to which its shareholders belong. All of these factors become part of how Wakatū and its shareholders continuously negotiate the dance that indigenously owned enterprises must perform ${ }^{133}$ as they strive to simultaneously maintain business legitimacy ("strategic plan!") and indigenous bona fides ("500 years!") - a dance that often seems paradoxical to outsiders. ${ }^{134}$ Tying the activities of the business to the history of its affiliated tribes is utterly crucial to this enterprise.

People involved with the corporation become invested in policing the boundaries of the relationships between the corporation, the tribes, and the shareholders because what is at stake is, at its root, an ontological question: what is an indigenous - but not indigenously ownedcorporation? People remake the corporation in their own (very complex) image as an intending subject, transforming it into what is held to be an ethically accountable thing. Further, the people involved in running the corporation construct themselves as ethically accountable people in light of their agency (or lack of agency) in shaping the way the corporation acts in the world. The Māori incorporation might, therefore, be considered to be bound as much by social and cultural demands as it is by regulatory ones.

But there are some characteristics of the Māori incorporation, which do not exist in the Contingent Corporation, that are of particular salience here. In a Māori incorporation, entity status is assumed, while personhood is not. Orts makes an argument for an institutionalist theory of the firm by powerfully articulating the benefits of the continued relevance of the corporate personhood concept. ${ }^{135}$ This argument makes

133. See generally Elizabeth A. Povinelli, The Cunning of ReCognition: Indigenous ALterities AND THE MAKING OF AUSTRALiAn Multiculturalism (2002).

134. See generally Beth A. Conklin, Shamans Versus Pirates in the Amazonian Treasure Chest, 104 Am. Anthropologist 1050 (2002); Beth A. Conklin \& Laura R. Graham, The Shifting Middle Ground: Amazonian Indians and Eco-Politics, 97 AM. ANTHROPOLOGIST 695 (1995); Susan E. Cook, The Business of Being Bafokeng, 52 CuRRENT ANTHROPOLOGY S151 (2011); Elizabeth A. Povinelli, Consuming Geist: Popontology and the Spirit of Capital in Indigenous Australia, 12 PUB. Culture 501 (2000); Povinelli, supra note 133.

135. See ORTS, supra note 38. 
sense conceptually, but leaves open the question of whether the personhood concept needs to be retained, and, as Orts acknowledges, it leaves open the question of whether it should be. ${ }^{136}$ The absence of corporate personhood in jurisdictions such as New Zealand demonstrates that the "person" idea is not a necessary one; "entity" serves the same purposes for conducting business and being held liable for harms. ${ }^{137}$ The difference matters because of the way that folk understandings of personhood become increasingly wound into jurists' delineations of the character of corporations and the rights that may properly be seen to be due to them. The embrace of "entity" terminology might help discard the metaphorical baggage that has made it so easy for corporate power enthusiasts to extend the constitutional rights of the corporation. An institutional theory of the corporation does not require the legal category of the corporate person. ${ }^{138}$

The New Zealand Māori incorporation is something separate-it is an entity with its own interests - but it is also connected to the values of this community. Its nature as an "indigenous corporation" (as opposed to just "Māori incorporation" or "indigenously owned corporation") comes neither through its status as person nor through the values, rights, and interests of its individual shareholders transduced magically into it, à la the Contingent Corporation. The "indigeniety" of the corporation is possible as much because of the strict regulations put upon the corporation by the state as it is the traditions and priorities of the people.

The same might be said to be true for a Black corporation, a Catholic corporation, or a Jewish corporation in the United States. To the extent each of these corporations may meaningfully be said to possess these attributes, it is made so not merely by courts' imprimatur or by a unilateral decision from its controlling shareholders, but by processes such as those I outline in the case of New Zealand Māori incorporation. Personal attributes of controlling stockholders or managers may factor in, but so will the norms and expectations of workers, lenders, customers, the relevant community, and other constituencies. Law will matter too. For example, the specifics of state corporate law will be one of many factors held in tension. Law will shape the social characteristics of the corpora-

136. Id. at $18-19$.

137. The main thrust of Orts's argument is against aggregate views of the firm-his emphasis is upon demonstrating that the firm has ontological (as well as imagined) reality as person or entity, not deciding which of the two terms is better to use. See id.

138. On the other hand, some type of entity status does appear to be crucial, or at least is so useful as to have been corralled by progressives since at least Dodd's 1932 discourse with Berle, in opposing shareholder-centric theories of the firm. See generally E. Merrick Dodd, Jr., For Whom Are Corporate Managers Trustees?, 45 HARV. L. REV. 1145 (1932). 
tion-but the meaning of corporate personal characteristics in relation to the law will come from these contextual factors.

In short, what I seek to emphasize here is a cultural conception of the corporation, embracing its radical heterogeneity. Rather than being a "solid" body that may be conceived of in direct analogy to an individual, the corporation is "particulate" and particular. I have thus aimed to underline the way the corporation is constructed of junctures that disassemble and assemble themselves at every moment in time. ${ }^{139}$ This friction, this tension, is productive for the corporation. It is a process of what some philosophers would call "being-at-work-staying-itself": the thing is made real—"stable" - by means of this constant internal tension. ${ }^{140}$

\section{CONCLUSION: THE LIVING CORPORATION}

Sociologist Philip Abrams once noted a curious problem in undertaking scholarship in regard to the state. The difficulty of studying the state, it seemed, was that scholars, while disaggregating the concept in their theorizing, found it necessary in practice to act as if it were a bounded, agentive, solid thing. ${ }^{141}$ Anthropologists have similarly discussed this situation through scholarly discourse in regard to the corporation: failing to demystify it, we tend to see it only as smooth, all-powerful, and unknowable. ${ }^{142}$

It thus becomes easy to imagine corporate cultural characteristics as analogous to the personal characteristics of an individual. The cases I have outlined reveal this assumption, but the courts leave untheorized its motivations. The vision of the corporation thus enacted echoes versions of an early twentieth-century corporatism characterized by viewing the corporation as necessarily imbued with the spiritual or moral character of the human community involved with it. As the work of Adolf Berle and Émile Durkheim reminds us, however, the generation of corporate personal characteristics is a complex process.

To understand them, you have to get down to the bones and the body and the breath of things: to the way people imagine agency and personality, the way they imagine history, and the way people imagine the boundaries and shape of the corporation. Opening this particular $76(2005)$

139. See AnNa Lowenhaupt Tsing, Friction: An ETHNOGRAPHY of Global CONNECTION

140. Joe SACHS, ARISTOTLE's Physics: A GUIDEd Study 21-23 (1995). (1988).

141. See Philip Abrams, Notes on the Difficulty of Studying the State, 1 J. Hist. Soc. 58

142. See Marina Welker, Notes on the Difficulty of Studying the Corporation, 39 SEATTLE U. L. REV. 397 (2016); see also Aiello \& Brooks, supra note 32. 
black box ${ }^{143}$ to reveal the fluid nature of the corporation requires an understanding of the way people undertake the reinscription of boundaries between persons and things, and the establishment and cutting of new tendrils of networks ${ }^{144}$ so that, in Eric Hirsch's words, "a singular identity can be effected."145

I have outlined a modern anthropological concept of culture characterized by attention to process and movement. Approaching the corporation in this anthropological way allows us to see the meaning-laden contingency of these organizations and the grounded processes by which they are shaped into different types of responsibility-holding entities. What might we do with this approach?

The Court's ruling in Hobby Lobby leaves us to work out what it means for future cases. What characteristics make a corporation a proper subject of the ascription of personal rights? In deciphering this question, other analyses might have us focus upon, for example, the official corporate values promulgated by the corporation's leadership. The modern cultural anthropological analysis I articulate will chiefly concern itself with formless and directionless, yet productive, tensions, such as those described in Part III. An analysis of the cultural character of the corporation focusing on unilateral edicts or official stances would likely miss that simmering Durkheimian froth of mores, ideas, tendencies, judgments, and moralities coming from the top of the organization, from the bottom, and from all sorts of elsewheres. ${ }^{146}$

The Court of today seeks clarity and a general applicability in undertaking its analysis and in constructing its opinions - a fine goal. But in relation to the personal rights cases, a deeper analysis is necessary. If corporations are going to be naturalized in the manner in which these cases demonstrate, we need to pay very thoughtful attention to the nature, context, and character of the corporations and the rights at issue in order to discern the proper terms of these personal rights extended to

\footnotetext{
145. Eric Hirsch, Property and Persons: New Forms and Contests in the Era of Neoliberalism, 39 ANN. REV. ANTHROPOLOGY 347, 356 (2010).

146. As American law explores the nature and limits of personal rights as applied to the scattered bodies that are corporations, anthropology's theoretical and methodological contributions can also help crack other issues the courts have left unclear. Take, for instance, the relationship between culture and corporate law in determining "the people" involved with the corporation to be looked to as the source of a corporation's "belief" or racial identity, or what characteristics ought to be considered in deciphering whether a corporation's beliefs are "sincerely held."
}

143. Johnson, supra note 30 . (1996).

144. See Marilyn Strathern, Cutting the Network, 2 J. Royal AnthropologiCAL InST. 517 
[Vol. 39:353

them. We must get into just those messy details and questions of context that the Court has sought to avoid.

The stakes here are high. Cultural theory does not merely allow us to describe more accurately the life and the law of corporations; it also contains normative implications. The Supreme Court's simplified conceptualization of corporations supports doctrine that hurts important human interests, obscuring or enervating what should be rich conversations about heterogeneity, responsibility, and the admixture of business and social values. Serious attention to cultural analysis within corporate law will help us to identify better legal rules and build better institutions. 